\title{
Tertib al-Jam' dan al-Naskh dalam Mukhtalif al-Hadīth Menurut Sharaf al-Quḍāh: Satu Analisis
}

\section{The Sequence of al-Jam' and Al-Naskh Methodology in Mukhtalif al-Hadith Solution: Analysis the View of Sharaf al- Quḍah}

\author{
Mohd Solleh Ab Razak \\ School of Humanities, Universiti Sains Malaysia, 11800 Pulau Pinang, Malaysia. \\ solahuddin_ayyub@yahoo.com \\ Roshimah Samsudin \\ School of Humanities, Universiti Sains Malaysia, 11800 Pulau Pinang, Malaysia. \\ roshimah@usm.my
}

DOI: https://doi.org/10.22452/usuluddin.vol49no1.4

\begin{abstract}
The method used by hadith scholars in the issue of contradiction between hadith which is termed as Mukhtalif al-Hadith usually involves three manhaj, namely al-Jam; al-Naskh and al-Tarjīh. In principle, the scholars of hadith arrange the order by putting al-Jam ' as the first, then al-Naskh and followed by al-Tarjīh. However, a contemporary hadith researcher, Sharaf al-Qudāh, was found to have presented a different order as compared with presented by hadith scholars. Therefore, this article aims to examine the views of Sharaf al-Qudāh regarding the sequence of manhaj solution of Mukhtalif al-Hadith based on the manhaj of hadith scholars. To implement this purpose, the writer is used library research based on qualitative research through contents analysis in order to record and analysis data. The finding of this research shows that the sequence of al-Hadith methodology which is proposed by Sharaf alQudāh is acceptable among muhaddithin even though it is not clearly stated in Muștalah al-Hadith writings. Accordingly, this writing is the way to enhance the understanding in accordance with the sequence of aplication methodology amongs the muhaddithin in order to eliminate the contradiction between al hadith.
\end{abstract}

Keywords: Sequence, Mukhtalif al-Hadīth, Sharaf al-Qud̄āh, Muhaddithīn

Abstrak
Kaedah yang digunakan oleh ulama hadith dalam isu percanggahan
antara hadith secara zahir yang diistilahkan sebagai Mukhtalif al-Hadith
lazimnya melibatkan tiga manhaj iaitu al-Jam', al-Naskh dan al-Tarjih.
Secara prinsipnya, ulama hadith menyusun tertib dengan mendahulukan 
al-Jam', kemudian al-Naskh dan kemudian al-Tarjih. Namun, seorang pengkaji hadith kontemporari iaitu Sharaf al-Qudāh didapati mengemukakan tertib yang berbeza berbanding tertib yang dikemukakan oleh ulama hadith. Oleh itu, artikel ini bertujuan untuk mengkaji pandangan Sharaf al-Qudāh berkaitan tertib manhaj penyelesaian Mukhtalif al-Hadìth berdasarkan manhaj ulama hadith. Untuk mencapai matlamat ini, kaedah kepustakaan berdasarkan kajian kualitatif melalui reka bentuk analisis kandungan digunakan sepenuhnya dalam proses pengumpulan dan penganalisisan data. Dapatan kajian menunjukkan bahawa tertib yang dikemukakan oleh Sharaf al-Qudāh merupakan tertib yang disepakati oleh para muhaddìthin sekalipun tertib tersebut tidak dinyatakan secara jelas di dalam karya-karya Muștalah al-Hadīth. Dengan itu, hasil dapatan dalam kajian ini dapat meluruskan kefahaman tentang tertib aplikasi metodologi yang dikemukakan oleh para muhaddìthīn dalam menghilangkan percanggahan dan keraguan antara hadith.

Kata kunci: Tertib, Mukhtalif al-Hadīth, Sharaf al-Quḍāh, Muhaddīthīn

\section{Pendahuluan}

Mukhtalif al-Hadìth merupakan salah satu cabang terpenting dalam ilmu hadith. Ia merupakan satu cabang ilmu yang perlu diketahui oleh para ulama daripada bidang hadith, fiqh, usul dan lain-lain bidang. ${ }^{1}$ Atas kepentingan ini, para muhaddithīn dan pengkaji hadith daripada pelbagai generasi menumpukan perhatian untuk mengkaji secara menyeluruh lagi mendalam bagi menyelesaikan permasalahan hadith yang dibincangkan dalam ilmu ini. ${ }^{2}$

Abū Zakariyyā Yaḥyā bin Sharaf al-Nawāwī, Irshād Ṭullab al-Haqū'iq ilā Ma'rifah Sunan Khayr al-Khalā'iq, ed. Nuruddin 'Itr (Damsyik: Dār alYamamah, 2002), 571.

2 Berkaitan hal ini, para Muhaddithin telah berusaha bersungguh-sungguh membincangkan berkaitan ilmu Mukhtalif al-Hadīth di dalam karya-karya mereka. Terdapat tiga pendekatan para Muhaddithīn dalam membincangkan ilmu ini. Pertama: perbincangan di dalam karya 'Ulūm al-Hadīth dan Muștalah al-Hadith. Melalui karya ini, para Muhaddithīn menggunakan istilah yang berbeza-beza, antaranya ialah Mukhtalif al-Hadīth, al-Akhbar al-Lātī la Mu'āridh laha bi Wajh min al-Wajh dan Ta'ārud al-Akhbār. Walaupun demikian, istilah Mukhtalif al-Hadìth adalah istilah yang paling popular yang digunakan di dalam karya-karya 'Ulüm al-Hadìth dan Muștalah al-Hadìth. Kedua: perbincangan di dalam karya-karya khusus yang menghimpulkan hadith-hadith. Bentuk ini melibatkan tokoh-tokoh utama dalam bidang hadith seperti al-Bukhārī dalam Șaḥịhnya, al-Tirmidhī 
Antara fokus utama perbincangan Mukhtalif al-Hadith ialah manhaj yang diaplikasikan oleh para muhaddithīn dalam merungkai percangahan yang berlaku antara dua hadith. Berhubung hal ini, para muhaddìthin mengemukakan manhaj alJam', al-Naskh dan al-Tarjīh dalam menyelesaikan permasalahan Mukhtalif al-Hadīth. ${ }^{3}$ Menurut Sa'd al-Dusārī, ketiga-tiga manhaj ini disepakati oleh seluruh para muhaddithīn. Namun terdapat muhaddithin yang menambah manhaj yang keempat iaitu alTawaqquf, namun manhaj ini diperselisihkan oleh para ulama. ${ }^{4}$

dalam Jāmi'nya, Ibn Khuzaymah dalam Ṣaḥịnnya, al-Bayhāqī dalam Sunannya dan banyak lagi. ${ }^{2}$ Perbincangan ini melibatkan hadith-hadith yang terdapat di dalam sesuatu bab atau pada bab-bab yang berlainan. Ketiga: perbincangan di dalam karya-karya Mukhtalif al-Hadith secara khusus dan terperinci bagi membincangkan tentang ilmu ini. Antara tokoh dan karya utama ialah al-Shāfi'ī melalui karyanya Ikhtilaf al-Hadìth, Ibn Qutaybah melalui karyanya Ta'wīl Mukhtalif al-Hadìth, al-Ṭahāwī melalui karyanya Mushkil al-Athār dan banyak para ulama yang menghasilkan karya Mukhtalif al-Hadīth secara lebih terperinci dan tersusun. Lihat Usāmah bin 'Abd Allāh Khayyāt, Mukhatalif al-Hadīth Bayna al-Muhaddīthīn wa alUșūiyyyin al-Fuqahā' (Beirut: Dār Ibn Hazm, 2001), 10. Abū 'Amrū 'Uthmān bin 'Abd al-Raḥman al-Shahrazūrī Ibn Șalāḥ, Muqaddimah Ibn alȘalạh (Kaherah: Dār al-Ḥadīth, 2010), 262-263. Abū Zakariyyā Yahyyā bin Sharaf al-Nawāwī, Al-Taqrīb wa al-Taysīr li Ma'rifah Sunan al-Bashīr wa al-Naḍir, ed. Muḥammad 'Uthmān al-Khasyat (Beirut: Dār al-Kitab al'Arabī, 1985), 90. Ismā'̄̄l bin 'Umar Ibn Kathīr, Ikhtișār 'Ulūm al-Hadīth, ed. Aḥmad Muhammad Shākir (Beirut: Dār al-Kutub al-'Ilmiyyah, t.t.), 169170. Aḥmad bin 'Alī al-'Asqalānī Ibn Hajar, Nuzhah al-Naẓar fì Tawḍih Nukhbah al-Fikr fì Muștalah Ahl al-Athār, ed. Nūr al-Dīn 'Itr (Karachi: Maktabah al-Bushrā, 2012), 83-84. Abū 'Abd Allāh Muhammad bin 'Abd Allāh al-Hākim, Ma'rifah 'Ulūm al-Hadìth (Beirut: Dār al-Kutub al'Ilmiyyah, 1977), 129. Abū Bakr Aḥmad bin 'Alī bin Thābit al-Khāṭib alBaghdādī, Al-Kifāyah fì 'Ilm al-Riwà̃yah, ed. Abū 'Abd Allāh al-Suraqi dan Ibrāhīm Hamdi al-Madān̄̄ (Madinah: al-Maktabah al-'Ilmiyyah, t.t.), 2:558. Al-Hādī Rushu, Mukhtalif al-Hadīth wa Juhūd al-Muhaddīthīn fìh: Dirāsah Naqḍiyyah (Beirut: Dār Ibn Hazm, 2009), 350-490.

3 Ibn Șalāḥ, Muqaddimah Ibn al-Ṣalah, 262-263. Al-Nawāwī, al-Taqrīb wa al-Taysìr, 90. 'Abd al-Rahīm bin Ḥusayn al-'Irāqī, Sharh al-Tabṣrah wa alTadhkirah, ed. Māhir Yasīn al-Fahl dan 'Abd al-Lațîf al-Hamim (Beirut: Dār al-Kutub al-'Ilmiyyah, 2002), 108. Jalāl al-Dīn 'Abd al-Raḥman bin Ab̄̄ Bakr al-Suyūṭi, Tadrīb al-Rāwì fì Shah Taqrīb al-Nawāwì (Beirut: Dār alKutub al-'Ilmiyyah, 1979), 2:196.

4 Sa'd Fajhan al-Dusārī, Qawā 'id Raf' al-Ikhtilāef fì al-Hadīth al-Nabāwī, (Beirut: Muassasah al-Risālah, 2011), 177. 
Selain daripada perbincangan manhaj yang diaplikasikan oleh para muhaddithīn dalam ilmu ini, mereka turut memfokuskan berkaitan tertib manhaj tersebut. Secara dasarnya, para muhaddithīn berpandangan bahawa tertib aplikasi manhaj Mukhtalif al-Hadīth hendaklah mendahulukan al-Jam', kemudian al-Naskh, kemudian al-Tarjīh dan akhirnya al-Tawaqquf. ${ }^{5}$ Demikianlah tertib yang dikemukakan oleh para Muhaddithin di dalam kebanyakan karya-karya Muștalah al-Hadith. ${ }^{6}$

Walaupun demikian, seorang pengkaji hadith kontemporari iaitu Sharaf al-Qudah ${ }^{7}$ telah mengarang sebuah makalah berkaitan Mukhtalif al-Hadith secara khusus yang berjudul 'Ilm Mukhtalif al-Hadìth: Usuluh wa Qawā'iduh. ${ }^{8}$ Di dalam makalah tersebut, beliau telah mengemukakan tertib manhaj penyelesaian Mukhtalif al-Hadith yang berbeza dengan tertib yang dikemukakan di dalam karya-karya Muștalah al-Hadith. Perbezaan tersebut dapat diperhatikan daripada dua dua aspek:

i. Pembahagian al-Naskh kepada dua bahagian iaitu alNaskh al-Sarīh dan al-Naskh Ghayr al-Sarīh.

5 'Abd al-Rahīm al-Husayn al-'Iraqi, Sharh al-Tabșirah wa al-Tadhkirah, 2:109. Muhammad bin 'Abd al-Raḥman al-Sakhāwī, Fath al-Mughīth bi Sharh Alfiyah al-Hadìth, ed. 'Alī Hasan 'Alī (Mesir: Maktabah al-Sunnah, 2003), 4:67-70. Ibn Hajar, Nuzhah al-Nazar, 79. Muhammad Abū al-Layth al-Khayr Abādī, 'Ulūm al-Hadīth Așiluhā wa Mu'asiruhā (Selangor: Darul Syakir, 2011), 309.

$6 \quad$ Pengkaji akan memperincikan hal ini di dalam sub-topik 'Tertib al-Jam ' dan al-Naskh dalam Karya Mustalah al-Hadìth.'

7 Nama penuh beliau ialah Sharaf Mahmūd Muhammad al-Qudāh. Beliau dilahirkan pada 9 September 1951M di Perkampungan Munif, daerah 'Ajlun, Jordan. Beliau mendapat ijazah pertama dalam bidang Syariah di Universiti Dimasyq pada tahun 1973. Beliau menyambung peringkat Sarjana dalam pengkhususan hadith dan 'Ulum al-Hadith di Kuliyyah Usuluddin, Universiti al-Azhar pada tahun 1975. Seterusnya menyempurnakan Ijazah Doktor Falsafah di Universiti al-Azhar dalam pengkhususan yang sama pada tahun 1980. Beliau memegang jawatan sebagai Professor di University of Jordan pada tahun, 2002-2005, 2006-2009 dan 2010 sehingga kini. Beliau banyak menghasilkan pelbagai karya dan kajian ilmiah serta menghadiri pelbagai seminar peringkat antarabangsa dalam pelbagai cabang ilmu terutamanya dalam bidang hadith dan 'Ulum al-Hadith. Lihat, "Dr. Sharaf al-Qudah", laman sesawang The University of Jordan, dicapai 10 Ogos 2020, http://eacademic.ju.edu.jo/S.Al-Qudah/Pages/AboutMe.aspx.

8 Karya ini diterbitkan di dalam Majallah Dirāsāt, al-Jāmi 'ah al-Urduniyyah, jilid 28, bilangan 8, tahun 2008 . 
ii. Tertib al-Naskh al-Sarīh lebih didahulukan berbanding dengan al-Jam" dan meletakkan al-Naskh Ghayr alSarịh selepas al-Jam ‘?

Berdasarkan perbezaan ini, pengkaji memfokuskan tertib yang dikemukakan oleh Sharaf al-Quḍāh sama ada tertib tersebut selari dengan manhaj para muhaddithin atau tertib tersebut merupakan satu teori baru yang beliau kemukakan dalam menetapkan tertib manhaj terhadap penyelesaian ilmu Mukhtalif al-Hadìth. ${ }^{10}$ Kajian ini penting kerana ia melibatkan struktur tertib manhaj penyelesaian terhadap hadith-hadith yang bercanggah dan tertib ini turut dinukilkan di dalam karya-karya lain oleh sebahagian pengkaji hadith kontemporari yang lain. ${ }^{11}$

\section{Definisi Mukhtalif al-Ḥadīth}

Perkataan mukhtalif merupakan bentuk isim fāil (pelaku atau subjek) yang diambil daripada kata kerja ikhtalafa. Kata dasar bagi perkataan ini ialah tiga huruf iaitu kha-lam-fa. Antonimnya ialah al-ittifaq (persepakatan). ${ }^{12}$ Menurut al-Fayyūmī, perkataan alkhalaf bermaksud gantian dan tukaran. Selain itu, ia turut bermaksud sesuatu kaum bertelagah dan berselisih, iaitu apabila salah satu daripada kedua-duanya berlawanan dengan pihak yang satu lagi. ${ }^{13}$ Manakala perkataan al-ikhtilaf dan al-mukhalafah

9 Sharaf al-Quḍāh, “IIm Mukhtalif al-Ḥadītḥ: Ușūluh wa Qawā‘iduh”, Majallāh Dirāsah al-Jāmi' 'ah al-Urduniyyah, jilid 28 (2001): 17.

10 Hal ini demikian kerana beliau mendakwa bahawa beliau tidak menemui sesiapa pun yang membezakan antara dua jenis al-Naskh ini sebagaimana kenyataan berikut:

"Saya tidak menemui sesiapa pun yang secara jelas membezakan antara alNaskh al-Sarīh dan al-Naskh Ghayr al-Sarīh, mendahulukan yang pertama ke atas al-Jam ' wa al-Tawfiq dan mengakhirkan yang kedua berbandingnya. Namun perbezaan tersebut merupakan satu tindakan yang betul yang mesti dilakukan. Mudah-mudahan ulama kita sebelum ini mengaplikasikannya sekalipun mereka tidak menjelaskannya. Oleh itu, perkara ini memerlukan penjelasan secara nyata." Lihat Sharaf al-Quḍāh, Al-Minhaj al-Hadīth $f \grave{\imath}$ 'Ulūm al-Hadīth (Jordan: al-Akadimiyyūn li al-Nashr wa al-Tawzī', 2003), 138.

11 Antaranya ialah Faisal Ahmad Shah melalui bukunya Kaedah Tepat Memahami Hadis. Lihat Faisal Ahmad Shah, Kaedah Tepat Memahami Hadis (Kuala Lumpur: Penerbit Universiti Malaya, 2015), 172-195.

12 Aḥmad bin Muḥammad bin 'Alī al-Fayyūmī, al-Miṣbāh al-Munīr fì Gharīb al-Sharh al-Kabīr li al-Rafi 'i (Beirut: al-Maktabah al-'Ilmiyyah), 1:179.

13 Al-Fayyūmī, al-Miṣbāh al-Munīr, 1:179. 
menurut Ibn Manzur bermaksud dua perkara yang saling bercanggah dan tidak bersepakat. Oleh itu, setiap perkara yang tidak sama, maka ia bercanggah. ${ }^{14}$

Dari sudut istilah pula, para muhaddithīn telah mengemukakan pelbagai definisi. Namun, definisi tersebut hampir sama antara satu sama lain dengan wujudnya penambahan atau pengurangan terhadap isi kandungan definisi yang di kemukakan. Tokoh pertama yang membincangkan definisi Mukhtalif al-Hadìth ialah al-Shāfi ‘ 1 (w. 204H) ${ }^{15}$ sebagaimana berikut:

"Tidak harus kita jadikan dua hadith daripada Rasulullah SAW itu bercanggah buat selama-lamanya sekiranya dijumpai kaedah agar kedua-duanya dapat diamalkan, maka kita tidak boleh membatalkan salah satu daripada dua hadith itu kerana kewajipan kita beramal dengan kesemua hadith. Tidak harus kita kekalkan percanggahan melainkan perkara yang tidak boleh diamalkan buat selama-lamanya". ${ }^{16}$

Beliau turut menjelaskannya dalam al-Risālah sebagaimana berikut:

"Sesungguhnya tidak dinamakan dua hadith sebagai bercanggah selagi mana kedua-duanya wujud persamaan yang boleh menyatukannya. Sebaliknya, yang dinamakan percanggahan ialah hadith yang tidak dapat disatukan melainkan dengan menggugurkan hadith yang lainnya. Seumpama dua hadith dalam satu perkara; hadith ini menghalalkannya dan hadith ini pula mengharamkannya". ${ }^{17}$

Pada definisi pertama, al-Shāfi'ī menunjukkan bahawa Mukhtalif al-Hadìth ialah hadith yang bercanggah dengan hadith

14 Muhammad bin Mukarram Ibn Manzūur, Lisān al-'Arab (Beirut: Dār alȘādir, 1993), 9:82.

15 Beliau turut merupakan tokoh pertama yang menulis ilmu Mukhtalif alHadith secara sistematik melalui karyanya yang berjudul Ikhtilaf al-Hadith dan karya ini menjadi rujukan utama dalam ilmu ini. Lihat al-Suyūțî, Tadrīb al-Rāwī, 2:196. Al-Dusārī, Qawā 'id Raf' al-Ikhtilāf, 24. Al-'Irāqī, Sharh alTabșirah wa al-Tadhkirah, 2:108. Al-Sakhāwī, Fath al-Mughìth, 4:67 ; Muḥammad bin Ja'far al-Kattān̄̄, Al-Risālah al-Mustatrifah li Bayān Mashhur Kutub al-Sunnah al-Mușannafah (cet. 4, Beirut: Dār al-Bashā'ir alIslāmiyyah, 1986), 158.

16 Muhammad ibn Idrīs al-Shāfi‘'̄i, "Ikhtilāf al-Hadīth" dalam al-Umm, ed.. Rif'āt Fawzī 'Abd al-Muțālib (Beirut: Dār Ibn Hazm, 2011), 10: 272.

17 Muhammad ibn Idrīs al-Shāfi'‘̄̄, Al-Risālah, ed. Ahmad Muhammad Shākir, (Kaherah: Maktabah al-Shurūq al-Dawliyyah, 2005), 370. 
yang lain, namun mampu dileraikan percanggahan tersebut sehingga kedua-duanya mampu diamalkan dan tiada hadith yang ditinggalkan sekiranya mampu. Pada definisi kedua pula, beliau menjelaskan bahawa terdapat hadith bercanggah yang memerlukan salah satu hadith digugurkan iaitu tidak diamalkan. Daripada dua definisi ini, ia menunjukkan bahawa terdapat percanggahan hadith yang mampu diharmonikan dan diamalkan kesemuanya, serta terdapat juga percanggahan yang memerlukan salah satu hadith digugurkan. ${ }^{18}$

Al-Hakim (m. 405H) turut mendefinisikan Mukhtalif alHadīth sebagaimana berikut:

"Satu jenis ilmu daripada ilmu-ilmu bagi mengetahui sunahsunah Rasulullah SAW yang bercanggah dengan seumpamanya, lalu pengikut mazhab menjadikan salah satu daripadanya sebagai hujah. Sedangkan hal kedua-duanya sama dari sudut kesahihan dan ke-da 'if-an". ${ }^{19}$

Berdasarkan definisi tersebut, al-Hakim menetapkan bahawa Mukhtalif al-Hadìth merupakan hadith-hadith yang bercanggah sehingga salah satu hadith sahaja yang dijadikan hujah. Lebih daripada itu, al-Hakim turut meletakkan syarat bahawa kedua-dua hadith yang bercanggah mestilah mempunyai persamaan daripada sudut kesahihan dan ke-da if-annya.

Berdasarkan dua definisi yang dikemukakan oleh dua tokoh besar ilmu hadith daripada kalangan mutaqaddimīn, ${ }^{20}$ al-Shāfi' $\overline{1}$

18 Berkaitan hal ini, al-Shāfi' ‘̄̄ menyatakan sebagaimana berikut:

"Yang paling utama, seseorang berilmu tidak ragu-ragu terhadap ketetapan al-Sunnah dan menyedari bahawa hukum-hakam Allah SWT dan hukum hakam rasul-Nya tidak bercanggah dan ia bergerak di atas contoh yang satu". Kenyataan ini turut ditegaskan oleh para fuqahä', usuliyyīn dan muhaddithīn sebagaimana yang dinyatakan oleh Nafidh Hammad dan alDusārī. Bahkan mereka menisbahkan percanggahan ini berlaku berpunca daripada pada pandangan para mujtahid sahaja. Lihat al-Shāfi'ī, al-Risālah, 234. Nafidh Hammad, Mukhtalif al-Hadìth Bayn al-Fuqahā' wa alMuhaddithīn (Beirut: Dār al-Nawādir, 2009), 32. Al-Dusārī, Qawā 'id Raf' al-Ikhtilāf, 25.

19 Al-Hāàim, Ma 'rifah 'Ulūm al-Hadìth, 122.

20 Al-Malyabārī menjelaskan maksud al-mutaqaddimīn sebagaimana berikut:

"Sesiapa yang mempraktikkan bahagian pertama iaitu penilaian berdasarkan zahir sanad dalam mensahihkan dan mendaifkan hadith, maka dia berdasarkan manhaj al-Muta'akhkhirin, sekalipun dia berada pada zaman riwayat. Sebaliknya sesiapa yang mempraktikkan bahagian kedua iaitu berpegang dengan bukti-bukti tersebut, maka dia berdasarkan manhaj al- 
dan al-Hākim mempunyai pandangan yang sama berkaitan Mukhtalif al-Hadìth iaitu hadith-hadith yang bercanggah. Namun

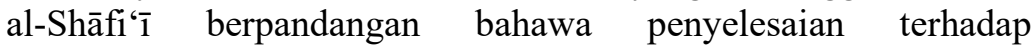
percanggahan tersebut tidak hanya terhad kepada pengguguran salah satunya sebagaimana pandangan al-Hakim, bahkan perlu mengutamakan agar kedua-dua hadith mampu diharmonikan sehingga kedua-duanya dapat diamalkan. Berbanding dengan alShāfi'‘̄, al-Hākim menetapkan di dalam definisinya bahawa kedudukan kedua-dua hadith mestilah sama daripada sudut kesahihan dan ke-da if-annya.

Seterusnya, berdasarkan dasar yang dikemukakan oleh alShāfi'ī di atas, Ibn Salah (m. 643H) membahagikan Mukhtalif alHadìth kepada dua bahagian:

i. Sesuatu yang berkemungkinan boleh diharmonikan secara al-Jam ' antara dua hadith yang berselisih.

ii. Sesuatu yang berbercanggah sehingga tidak mampu untuk diharmonikan antara kedua-dua hadith tersebut. Lalu diaplikasikan penyelesaian berdasarkan al-Naskh dan al-Tarjih. ${ }^{21}$

Kenyataan di atas menunjukkan bahawa Ibn Șalāḥ turut memasukkan hadith yang bercanggah namun boleh diharmonikan ke dalam perbincangan Mukhtalif al-Hadìth. Dalam hal ini juga, pengkaji mendapati al-Shāfi '‘ dan Ibn Șalāḥ tidak mengemukakan definisi yang jelas berkaitan Mukhtalif al-Hadith, sebaliknya sekadar membincangkan dari sudut pembahagian Mukhtalif alHadith.

Hal ini berbeza dengan al-Nawāwī (m. 676H), dimana beliau mengemukakan definisi yang lebih jelas. Menurut beliau, Mukhtalif al-Hadith ialah:

"Dua hadith yang bercanggah pada maknanya secara zahir, lalu diharmonikan antara kedua-duanya atau dikuatkan salah satunya". ${ }^{22}$

Mutaqaddimin, sekalipun dia berada pada zaman kontemporari”. Lihat Hamzah 'Abd Allāh al-Malyabārī, al-Muwāzanah Bayna al-Mutaqaddimīn wa al-Muta'akhkhirīn fì Taṣhịh al-Aḥādìth wa Ta 'liliha (Beirut: Dār Ibn Hazm, 2001), 18.

21 Ibn Șalāḥ, Muqaddimah Ibn al-Șalāh, 262-263.

22 Al-Nawāīī, Al-Taqrīb wa al-Taysīr, 90. 
Definisi ini meletakkan tiga aspek dalam Mukhtalif al-Hadith iaitu hadith yang bercanggah, percanggahan secara zahir dan hadith-hadith tersebut dapat diharmonikan atau dikuatkan salah satunya. ${ }^{23}$

Pada akhir fasa kematangan dan penyempurnaan pembukuan seni 'Ulūm al-Hadìth, ${ }^{24}$ Ibn Hajar al-'Asqalānī (m. 852H) mengemukakan definisinya dengan lebih terperinci sebagaimana berikut:

"Hadith Maqbūl terbahagi kepada yang diamalkan dan yang tidak diamalkan. Sekiranya ia terselamat daripada sebarang percanggahan iaitu tidak datang hadith yang bercanggah dengannya maka ia merupakan hadith al-muhkam, contohcontohnya banyak. Sekiranya terdapat percanggahan, maka tidak terlepas sama ada wujudnya percanggahan itu adalah maqbūl seumpamanya atau ia mardūd. Bagi percanggahan yang kedua (iaitu mardūd), ia tidak memberi kesan kerana hadith yang kuat tidak terkesan dengan percanggahan dengan hadith lemah. Namun, seandainya percanggahan dengan hadith yang sama kedudukannya, maka ia tidak terlepas daripada kemungkinan, sama ada mampu diharmonikan antara dua dalil tanpa melampau atau tidak. Sekiranya mampu diharmonikan, maka bahagian ini dinamakan sebagai Mukhtalif al-Hadìth. ${ }^{25}$

23 Berdasarkan definisi ini jugalah, ramai daripada al-muhaddithin yang mengguna pakai definisi ini seperti Ibn Jama'ah, al-Tibriz̄̄, al-'Irāqī, alSuyūṭ̂̄ dan lain-lain. Demikian juga para pengkaji hadith kontemporari seperti Nafidh Hammad. Lihat Muhammad bin Ibrāhīm Ibn Jama'ah, AlManhal al-Rāwī fì Mukhtașar 'Ulūm al-Hadìth al-Nabāwī, ed. Mahy al-Dīn 'Abd al-Raḥman Ramāḍān (Damsyik: Dār al-Fikr, 1983), 60. Abū al-Hasan 'Alī bin Abī Muhammad 'Abd Allāh al-Tibrizī, Al-Kāfì fì 'Ulūm al-Hadìth, ed. Abū 'Ubaydah Mashhūr bin Hasan 'Alī Salmān (Amman: al-Dār alAthāriyyah, 2008), 298. Al-'Irāqī, Sharh al-Tabșirah wa al-Tadhkīrah, 2:108. Al-Suyūṭī, Tadrīb al-Rāwì, 2: 196. Nafidh Hammad, Mukhtalif alHadìth, 17.

24 Sebagaimana yang dinyatakan oleh Nūr al-Dīn 'Itr. Lihat Nūr al-Dīn 'Itr, Manhaj al-Naqd 'Inda 'Ulamā' al-Hadīth (Beirut: Dār al-Fikr, 1979), 6569.

25 Ibn Hajar, Nuzhah al-Nazar, 76. 
Definisi yang dikemukakan oleh Ibn Hajar di atas telah mengeluarkan percanggahan antara hadith maqbül dan mard $\bar{u} d$ dalam perbincangan Mukhtalif al-Hadìth sebagaimana al-Hakim. ${ }^{26}$

Akhirnya, pengkaji menyimpulkan definisi Mukhtalif alHadith ialah hadith Maqbūl yang bercanggah dengan hadith yang seumpamanya dengan percanggahan secara zahir sahaja.

\section{Skop dan Metodologi}

Dalam menjalankan kajian ini, pengkaji telah menetapkan skop kajian agar lebih terfokus dan terarah. Oleh itu, kajian ini secara spesifik hanya memfokuskan perbincangan terhadap tertib al-Jam ' dan al-Naskh dalam Mukhtalif al-Hadith berdasarkan makalah yang dihasilkan oleh Sharaf al-Quḍāh yang berjudul 'Ilm Mukhtalif al-Hadīth: Usuluh wa Qawā'iduh sahaja. Pemilihan makalah tersebut adalah atas justifikasi perbincangannya yang berbentuk terperinci berkaitan dengan tertib al-Jam ' dan al-Naskh. Hal ini bermakna makalah tersebut disorot perbincangannya untuk dilakukan analisis secara khusus sekaligus menandakan bahawa karya-karya beliau yang lain tidak akan dirujuk melainkan ketika perlu iaitu sebagai sokongan sahaja. Justeru, berdasarkan pemerhatian terhadap karya-karya beliau, pengkaji mendapati tidak terdapat perbincangan yang lebih terperinci berkaitan kajian ini melainkan dalam makalah ini sahaja. Malah, dalam penulisan beliau yang bertajuk al-Minhaj al-Hadìth fì 'Ulüm al-Hadìth memperlihatkan bahawa beliau sendiri didapati turut menyarankan agar para pembaca merujuk kepada makalah ini untuk mendapatkan penjelasan yang lebih mendalam berkaitan perbincangan Mukhtalif al-Hadìth dan tertib penyelesaiannya. ${ }^{27}$ Selain itu, kajian ini turut membataskan perbincangan kepada manhaj muhaddithīn sahaja. Hal ini secara tidak langsung

26 Definisi ini jugalah yang digunapakai oleh Shabbir bin Aḥmad al-'Uthmān̄̄ al-Hindī, Muhammad Abū al-Layth al-Khayr Abādī, Munīrah al-'Iskir dan lain-lain. Rujuk Shabbir bin Aḥmad al-'Uthmān̄̄, Mabādi' 'Ilm al-Hadīth wa Ușūluh, ed. 'Abd al-Faț̣āạ Abū Ghuḍāh (Kaherah: Dār al-Salam, 2016), 302-303. Muḥammad Abū al-Layth, 'Ulūm al-Hadīth, 305. Munīrah bint 'Abd Allāh bin Șālị al-'Iskir, Mukhtalif al-Hadīth Inda al-Qādì Ibn al'Arabī fì Kitābihi al-Masālik fì Sharh Muwațțā' Mālik: Jam 'wa Dirāsah, (tesis kedoktoran, Jāmi'ah al-Mālik Sa'ūd, Su'ūdī, 2015), 18-20.

27 Sharaf al-Quḍāh, Al-Minhaj al-Hadìth fì 'Ulūm al-Hadìth, 138. 
memberi indikasi bahawa manhaj para sarjana lain seperti manhaj fuqah $\bar{a}$ ' dan lain-lain tidak termasuk dalam kajian ini.

Artikel ini mengaplikasikan kaedah kajian kepustakaan melalui reka bentuk analisis kandungan dalam proses pengumpulan data-data yang berkaitan dengan tertib al-Jam 'dan al-Nasakh dalam Mukhtalif al-Hadith. Pengkaji mengumpulkan pelbagai pandangan dalam kalangan muhaddithìn berdasarkan karya-karya utama Muștalah al-Hadìth tentang isu berkenaan. Kemudian, data-data yang diperolehi daripada pelbagai sumber primer dan sekunder tersebut dianalisis berdasarkan kaedah induktif dan deduktif agar dapat menghasilkan satu analisis kesimpulan secara menyeluruh terhadap isu tertib al-Jam ' dan alNaskh dalam Mukhtalif al-Hadith yang dikemukakan oleh Sharaf al-Qựāh.

\section{Hasil dan Dapatan}

\section{Tertib al-Jam' dan al-Naskh Menurut Muḥaddithīn dalam} Karya Muṣtalaḥ al-Ḥadīth

Para ulama bersepakat bahawa terdapat tiga manhaj dalam penyelesaian Mukhtalif al-Hadīth iaitu al-Jam', al-Naskh dan alTarjih. ${ }^{28}$ Manakala tertib manhaj secara umumnya daripada kalangan muhaddithīn sebagaimana berikut:

$\begin{array}{ll}\text { i. } & \text { Manhaj al-Jam ' } \\ \text { ii. } & \text { Manhaj al-Naskh } \\ \text { iii. } & \text { Manhaj al-Tarjīh }{ }^{29}\end{array}$

Walaupun demikian, tertib ini tidaklah diterima secara mutlak. Hal ini demikian kerana terdapat perbezaan daripada kalangan ulama hadith tatkala mengemukakan tertib tersebut. Sebahagian muhaddithīn di dalam karya-karya Muștalah al-Hadìth menetapkan secara jelas al-Jam ' merupakan manhaj pertama yang dipraktikkan dalam penyelesaian Mukhtalif al-Hadìth, seterusnya al-Naskh dan al-Tarjīh. ${ }^{30}$ Sebahagian Muhaddithīn yang lain pula tidak menetapkan tertib sedemikian, sebaliknya mereka

\footnotetext{
28 Al-Dusārī, Qawā 'id Raf' al-Ikhtilāf, 177.

29 Al-'Irāqī, Sharh al-Tabșirah wa al-Tadhkīrah, 2:109. Al-Sakhāwī, Fath alMughìth, 4:67-70. Ibn Hajar, Nuzhah al-Naẓar, 79. Muḥammad Abū alLayth, 'Ulüm al-Hadìth, 309.

30 Muhammad Abū al-Layth, 'Ulūm al-Hadìth, 309.
} 
membahagikan penyelesaian Mukhtalif al-Hadīth kepada dua bahagian:

i. Yang mampu diaplikasikan al-Jam .

ii. Yang tidak mampu diaplikasikan al-Jam; iaitu penyelesaian berdasarkan manhaj al-Naskh dan alTarjīh. ${ }^{31}$

Berdasarkan dua pendekatan dalam perbentangan para muhaddithīn di dalam karya-karya Muștalah al-Hadìth, maka ia membuka ruang terhadap penentuan manhaj pertama yang mesti diaplikasikan dalam penyelesaian Mukhtalif al-Hadìth sama ada secara al-Jam ' atau pun al-Naskh. Oleh yang demikian, manhaj alJam' tidak semestinya menjadi manhaj pertama yang perlu diaplikasikan secara mutlak dalam penyelesaian Mukhtalif alHadith. Namun para muhaddithin tidak berselisih pandangan bahawa manhaj al-Tarjīh diaplikasikan selepas al-Naskh.

Tambahan pula, terdapat hadith-hadith bercanggah yang mustahil dapat diharmonikan melalui manhaj al-Jam ' disebabkan percanggahan yang nyata. Al-Shāfi' ${ }^{1} \overline{1}$ menyatakan hal tersebut sebagaimana berikut:

"Apabila dua hadith tiada kemungkinan melainkan wujudnya perbezaan sebagaimana perbezaan kiblat menghadap ke Baitul Maqdis dan Baitul Haram, maka salah satunya adalah Nāsikh dan keduanya adalah Mansūkh". ${ }^{32}$

Berdasarkan contoh perbezaan arah kiblat tersebut, maka manhaj al-Jam ' sama sekali tidak boleh diaplikasikan sekalipun ia disenaraikan di dalam sebahagian kitab Mustalah al-Hadìth sebagai manhaj yang pertama. Oleh itu, manhaj al-Naskh hendaklah diutamakan. Keputusan ini turut ditegaskan oleh alSuyuti sebagaimana kenyataan berikut:

31 Ibn Șalāḥ, Muqaddimah Ibn al-Ṣalāh, 262-263. 'Abd al-Raḥim bin alHusayn al-'Irāqī, Al-Taqyīd wa al-Idah Sharh Muqaddimah Ibn al-Ṣalāh, ed. 'Abd al-Raḥman Muḥammad 'Uthmān (Madinah: al-Maktabah alSalāfiyyah, 1969), 285-286. Al-Nawāwī, Irshād Tullab al-Haqā'iq, 573572. Abū Hafs 'Umar bin Aḥmad Ibn al-Mulaqqīn, Al-Mughnī' fì 'Ulūm alHadìth, ed. 'Abd Allāh bin Yūsuf al-Juday' (Arab Saudi: Dār Fawwaz, 1992), 2:481-482. Al-Suyūțī, Tadrīb al-Rāwī, 2:197-198. Ibn Jamā'ah, AlManhal al-Rāwī, 60-61. Al-Tibrizī, Al-Kāfì fì 'Ulūm al-Hadīth, 298-304. Ibn Kathīr, Ikhtișār'Ulūm al-Hadìth, 170.

32 Al-Shāfi‘‘̄, Ikhtilāf al-Hadìth, 40. 
"Tidak boleh al-Jam ' antara kedua-dua hadith dengan manamana kaedah, sekiranya kita mengetahui salah satunya merupakan Nāsikh dengan kaedah yang telah lalu, maka kami dahulukannya". ${ }^{33}$

Berdasarkan kenyataan-kenyataan di atas, apabila dua hadith bercanggah dalam bentuk percanggahan yang nyata, maka manhaj al-Naskh perlu diutamakan berbanding manhaj al-Jam: Walau bagaimana pun, al-Naskh yang diutamakan berbanding al-Jam ' ialah apabila al-Naskh tersebut disebutkan secara nas dan jelas.

\section{1) Perbincangan Tentang al-Jam ‘}

Al-Jam' daripada sudut bahasa merupakan kata dasar daripada perkataan ja-ma-'a. Perkataan ini mempunyai pelbagai makna, antaranya ialah menghimpunkan sesuatu dengan cara mendekatkan sebahagian dengan sebahagian yang lain, ${ }^{34}$ menyatukan sesuatu yang terpisah, ${ }^{35}$ menghimpunkan sesuatu daripada sini dan sana sekalipun tidak menjadikan ia seumpama sesuatu yang sama ${ }^{36}$ dan keazaman. ${ }^{37}$

Al-Jam' daripada sudut istilah pula mempunyai pelbagai definisi sebagaimana yang telah dikemukakan oleh para muhaddithīn. Al-Shāfi'‘̄ mengemukakan maksud al-Jam ‘ sebagaimana berikut:

"Kami tidak temui sesuatu daripadanya (Nabi Muhammad SAW) dua perkara yang bercanggah lalu kami mampu menyelesaikan percanggahannya- melainkan kami dapat menemui satu sudut yang dapat difahami bahawa ia tidaklah bercanggah dan ia termasuk dalam salah satu jenis-jenis yang telah kami sebutkan kepada kamu". ${ }^{38}$

33 Al-Suyūțī, Tadrīb al-Rāwī, 198. Selain al-Suyūṭī, Ibn Kathīr turut mempunyai pandangan yang sama. Lihat Ibn Kathīr, Ikhtiṣār 'Ulūm alHadìth, 170.

34 Ạ̣mad bin Fāris bin Zakariyyā Ibn Fāris, Mu jam Maqāyis al-Lughah, ed. 'Abd al-Salam Muḥammad Hārun (Kaherah: Dār al-Fikr, 1979), 1:479.

35 Muḥammad bin Ya'qūb al-Fayrūz Abādī, Al-Qāmus al-Muhịt, ed. Muhammad Na'īm al-'Arqasusi (Beirut: Muassasah al-Risālah, 2005), 68. Ibn Manzūur, Lisān al-'Arab, 1:45.

36 Al-Fayrūz Abādī, Al-Qāmūs al-Muhịț, 68.

37 Muhammad bin Abī Bakr al-Rāzī, Mukhtār al-Șiḥah (Beirut: Maktabah Lubnān Nashirun, 1995), 119.

38 Al-Shāfi ‘’̄, Al-Risālah, 272. 
Selain al-Shāfi' $\overline{1}$, al-Nawāwī turut menjelaskan bahawa alJam' ialah dua hadith yang boleh diselaraskan dan wajib beramal dengan kedua-duanya, sekalipun ucapannya dapat difahami secara lebih umum untuk sesuatu faedah. ${ }^{39}$

Berdasarkan definisi yang dikemukakan oleh al-Shāfi ‘ī dan al-Nawāwī, kedua-duanya sekadar menyebut dasar utama dalam aplikasi manhaj al-Jam 'iaitu menafikan percanggahan antara dua hadith dengan mengharmonikan dan menyelaraskan dua hadith tersebut. Lantas kedua-dua hadith tersebut dapat diamalkan tanpa perlu membatalkan salah satunya.

\section{2) Perbincangan Tentang al-Naskh}

Al-Naskh merupakan satu perkataan yang berasal daripada nasakha-yansukhu. Perkataan ini mendatangkan dua maksud: iaitu menghilangkan atau menyalin sesuatu. ${ }^{40}$ Daripada sudut istilah pula, muhaddithiīn memberikan beberapa pelbagai definisi dengan ungkapan yang pelbagai. Bahkan pengunaan lafaz al-Naskh antara salaf dan khalaf juga berbeza penggunaannya.

Menurut Ibn al-Qayyīm, lafaz al-Naskh yang digunakan oleh salaf bagi menunjukkan takhsis al- 'am, taqyīd al-mutlaq, bayān al-mujmal, istithna' dan bentuk-bentuk yang dapat menghilangkan percanggahan hadith yang berlaku. ${ }^{41}$

39 Yaḥyā ibn Sharaf al-Nawāwī, Al-Minhaj Sharh Șah̄ị Muslim bin al-Hajjāj (Beirut: Dār Ihyā' al-Turath al-'Arabi, 1932), 1:35.

40 Muḥammad bin Muḥammad bin 'Abd al-Razzāq al-Zābid̄̄, Tāj al-'Arūs min Jawāhir al-Qāmūs (Beirut: Dār al-Hidāyah, t.t.), 7:355.

41 Ibn al-Qayyīm menyebutkan perkara ini sebagaimana berikut:

"Yang dimaksudkan oleh sekalian Salaf berkaitan al-Nāsikh wa al-Mansūkh ialah kadang-kadang menghilangkan hukum secara umum -ia merupakan istilah Muta'akhirin- dan kadang-kadang menghilangkan petunjuk al-'Am, al-Mutlaq, al-Zāhir dan selainnya: sama ada dengan Takhsis, Taqyīd, memahami Mutlaq secara Muqayyad atau huraian dan penjelasannya. Sehingga mereka menamakannya sebagai Istithna ${ }^{\prime}$, syarat dan sifat sebagai Nasakh kerana hal demikian mengandungi maksud menghilangkan petunjuk zahir dan menjelaskan maksudnya."

Hal ini turut ditegaskan oleh al-Shātịīi dan beliau mengemukakan beberapa contoh berdasarkan aplikasi para salaf dalam mengaplikasikan al-Naskh. Lihat Muhammad bin Abī Bakr al-Jawziyah Ibn al-Qayyīm, I'lam alMuqi in 'an Rabb al-'Alamīn, ed. Abū 'Ubaydah Mashhūr bin Hasan 'Alī Salmān (Arab Saudi: Dār Ibn al-Jawzī, 2002), 2:66. Ibrāhim bin Mūsā bin Muhammad al-Ghirnatī al-Shāțibī, Al-Muwāfaqāt, ed. Mashhūr bin Ḥasan 'Alī Salmān (Madinah: Dār Ibn 'Affān, 1997), 3:344. 
Walaupun demikian, Nafidh Hammad berpandangan bahawa kenyataan tersebut bercanggah dengan praktikal al-Shāfi' ${ }^{1} \bar{y}$ yang merupakan antara tokoh besar salaf. ${ }^{42}$ Menurutnya lagi, al-Shāfi ‘⿳亠丷⿵冂⿱十口 telah menulis tentang al-Naskh dan mengemukakan bukti serta contoh yang praktikal bagi menjelaskan bahawa terdapat perbezaan berkaitan al-Naskh dengan al-'umum dan al-khușuss. Bahkan beliau juga menjelaskan perbezaan antara al-Naskh dengan kefahaman yang luas di sisi para sahabat dan tabi'in. ${ }^{43}$

Walaupun demikian, pengkaji mendapati al-Shāfi'‘̄ tidak menyebut definisi al-Naskh secara jelas di dalam Ikhtilaf alHadīth berdasarkan definisi al-muta'akhirīn, ${ }^{44}$ namun beliau menyatakan definisinya di dalam al-Risālah secara ringkas, iaitu: "Makna al-Nasakh ialah meninggalkan kefarduannya". ${ }^{45}$

Menurut Mahmud Șidqī al-Habbash, berdasarkan makna yang telah dikemukakan oleh al-Shāfi '⿳亠丷⿵冂丶

42 Al-Shāfi'‘̄ diiktiraf sebagai seorang yang mahir dalam ilmu al-Naskh, sebagaimana kenyataan Aḥmad bin Ḥanbal sebagaimana berikut:

"Kami tidak mengetahui berkaitan al-Mujmal berbanding al-Mufassar dan kami tidak mengetahui Nāsikh al-Hadīth berbanding Mansūkhnya, sehinggalah kami duduk bersama al-Shāfi ‘’̄”.

Lebih daripada itu, al-Nawāwī menegaskan bahawa al-Shāfi'‘̄ merupakan orang pertama yang membicarakan ilmu ini. Lihat: Ibn Șalāḥ, Muqaddimah Ibn al-Ṣalāh, 256. Al-Nawāwī, Irshād Țullab al-Haqā’iq, 185. Al-Dusārī, Qawā 'id Raf' al-Ikhtiläf, 293.

43 Selain Nafidh Husayn Hammad, al-Dusārī turut berpandangan bahawa kitab al-Risālah karangan al-Shāfi'‘̄ menjelaskan makna al-Naskh dan beliau membezakan penggunaan tersebut dengan mengemukakan definisi dan contoh yang praktikal lagi terang bahawa al-Naskh bukanlah al-Takhșiṣ, alTaqyīd dan Istithnā'. Lihat Nafidh Hammad, "Manhaj al-Imām al-Shāfi' 'ī fì Nāsikh al-Ḥadīth wa Mansūkhihi”, dalam Mu’tamar al-Imām al-Shāfi ‘̄̄, ed. Shādī Hamzah Tabazah (Kuliyyah al-Ādāb wa al-'Ulūm al-Insāniyyah, Jāmi'ah al-Aqsa, 2012), 191. Al-Dusārī, Qawā 'id Raf' al-Ikhtilāf, 293.

44 Al-Shāfi'ī berkata:

"Pada hadith Nāsikh wa Mansükh, sebagaimana yang saya sifatkan dalam bab Qiblat, ia dimansuhkan dengan menghadap al-Bayt al-Harām. Apabila dua hadith tidak dapat difahami melainkan terdapat perbezaan, sebagaimana perbezaan kiblat ke arah al-Bayt al-Maqdīs dan al-Bayt al-Harām, maka yang pertamanya adalah Nāsikh dan keduanya adalah Mansūkh".

Lihat, al-Shāfi'ī, Ikhtilaf al-Hadìth, 40.

45 Al-Shāfi'‘' al-Risālah, 194. Penulis mendapati beliau menumpukan kepada contoh-contoh yang praktikal sebagaimana yang dibentangkan dalam bab Ibtidā' al-Nāsikh wa al-Mansūkh dan bab seterusnya. Lihat, al-Shāfi'‘̄, AlRisālah, 181-213. 
Naskh di sisi para ulama dan usuliyin yang datang selepas beliau. ${ }^{46}$ Antara muhaddithīn yang mengemukakan definisi ini ialah Ibn alȘalaāḥ sebagaimana berikut:

"Satu ungkapan berkaitan Rasulullah SAW yang membatalkan sesuatu hukum syarak yang terdahulu dengan hukum yang terkemudian". ${ }^{47}$

Menurut Ibn al-Șalāḥ, definisi ini merupakan definisi yang selamat daripada kritikan dan merangkumi definisi yang lain. Definisi ini menjadi pilihan bagi al-Nawāwī, ${ }^{48}$ al-'Irāqī ${ }^{49}$ alJurjān̄̄ ${ }^{50}$ Ibn Hajar ${ }^{51}$ dan al-Sakhāwī. ${ }^{52}$

\section{Analisis Tertib al-Jam'dan al-Naskh dalam Mukhtalif al- Hadīth Menurut Sharaf al-Quḍāh}

Sharaf al-Quḍāh membincangkan manhaj penyelesaian terhadap percanggahan antara hadith dan dalil-dalil yang lain di bawah tajuk hukm Mukhtalif al-Hadith..$^{53}$ Melalui perbincangan ini, beliau mengemukakan tiga pandangan para ulama dalam menentukan tertib pernyelesaian terhadap hal ini sebagaimana berikut:

i. $\quad$ Pandangan muhaddithin

Iaitu berdasarkan tertib berikut: al-Jam 'wa al-Tawfiq, al-Naskh, al-Tarjih dan al-Tawaqquf atau al-Radd.

ii. Pandangan jumhur ușūliyyīn Iaitu berdasarkan tertib berikut: al-Jam ' wa al-Tawfiq, al-Tarjīh, al-Naskh dan al-Radd, memilih salah satunya atau melakukan sekali bagi semua keadaan.

iii. Pandangan al-hanafiyyah

iv. Iaitu berdasarkan tertib berikut: al-Naskh, al-Tarjīh, al-Jam ' dan al-Tasaqut. ${ }^{54}$

46 Maḥmūd Șidq̄i al-Habbash, Al-Muwāzanah Bayna Manhajay al-Imāmayn al-Shăfi ‘̀ wa Ibn Qutaybah min Khilal Kitäbayhima Ikhtilāf al-Hadìth wa Ta'wīl Mukhtalif al-Hadīth (disertasi, al-Jāmi'ah al-Islāmiyyah Ghazzah, Palestin, 2001), 349.

47 Ibn Șalāh, Muqaddimah Ibn al-Șalāh, 257.

48 Al-Nawāwī, Irshād Tullab al-Haqū'iq, 185.

49 Al-'Irāqī, Sharh al-Tabșirah wa al-Tadhkīrah, 96.

50 'Alī bin Muhammad bin 'Alī al-Zayn al-Sharīf al-Jurjān̄̄, Kitāo al-Ta 'rīfāt (Beirut: Dār al-Kutub al-'Ilmiyyah, 1983), 240.

51 Ibn Hajar, Nuzhah al-Nazar, 78.

52 Al-Sakhāwī, Fath al-Mughīth, 4: 47-48.

53 Sharaf al-Quḍāh, 'Ilm Mukhtalif al-Hadìth, 13-27.

54 Sharaf al-Quḍ̄h, 'Ilm Mukhtalif al-Hadīth, 13-14. 
Berdasarkan tiga pandangan tersebut, Sharaf al-Quḍāh telah menegaskan bahawa pandangan muhaddithin merupakan pandangan yang lebih hampir kepada kebenaran. ${ }^{55}$ Setelah beliau membentangkan tertib tersebut, lantas beliau menganalisis setiap pandangan yang dikemukakan tersebut. Melalui analisis tersebut, Sharaf al-Quḍāh telah membuat perbezaan antara al-Naskh yang mengandungi penjelasan daripada Nabi Muhammad SAW atau sahabat dengan al-Naskh yang diketahui berdasarkan tarikh. Dalam hal ini, beliau mendahulukan al-Naskh yang jelas berbanding al-Jam' wa al-Tawfiq. Sebaliknya, al-Naskh yang tidak jelas maka diletakkan selepas al-Jam ' wa al-Tawfiq. ${ }^{56}$

Berdasarkan analisis tersebut, Sharaf al-Quḍāh telah mengemukakan tertib manhaj Mukhtalif al-Hadith yang menurut beliau ia merupakan pandangan yang al-rajih. Tertib tersebut adalah sebagaimana berikut:

$\begin{array}{ll}\text { i. } & \text { Menolak hadith da 'if } \\ \text { ii. } & \text { Al-Naskh al-Sarīh } \\ \text { iii. } & \text { Al-Jam` } \\ \text { iv. } & \text { Al-Naskh Ghayr al-Sarīh } \\ \text { v. } & \text { Al-Tarj̄̄h } \\ \text { vi. } & \text { Al-Tawaqquf. }{ }^{57}\end{array}$

Berdasarkan pandangan yang dikemukakan oleh Sharaf alQuḍāh di atas, pengkaji memfokuskan kepada dua aspek utama yang berkaitan dengan kajian ini sebagaimana berikut:

\section{[Pertama] Pembahagian al-Naskh Antara al-Naskh al-Ṣarīh dan al-Naskh Ghayr al- al-Șarīḥ}

Kedudukan tertib manhaj al-Naskh yang mesti diutamakan adalah tertib yang tidak mutlak sebagaimana manhaj al-Jam'. Justeru, keutamaan manhaj al-Naskh berbanding manhaj al-Jam ' memerlukan perincian yang lebih lanjut. Oleh yang demikian, Sharaf al-Quḍ̄h membezakan al-Naskh kepada dua aspek iaitu al-

55 Sharaf al-Qựāh, 'Ilm Mukhtalif al-Hadìth, 14.

56 Dalam hal ini beliau berpandangan bahawa tidak sah mengaplikasikan alJam ' wa al-Tawfiq terhadap hadith yang melarang menziarahi kubur dengan hadith yang membenarkannya, kerana telah jelas bahawa perkara kedua itu telah memansuhkan perkara yang pertama. Lihat Sharaf al-Quḍāh, IIm Mukhtalif al-Hadìth, 14.

57 Sharaf al-Quḍāh, 'Ilm Mukhtalif al-Hadìth, 17. 
Naskh al-Sarīh dan al-Naskh Ghayr al-Sarīh..$^{58}$ Perbezaan inilah yang menjadi pemisah antara tertib manhaj al-Naskh dalam menyelesaikan percanggahan antara hadith-hadith. Hal ini ditegaskan oleh al-Laknāwī sebagaimana berikut:

"Al-Naskh secara hakiki tidak akan berlaku melainkan dengan nas daripada al-Shari" yang menunjukkan hadith ini Nāsikh kepada hadith ini, atau sesuatu yang menunjukkan bukti yang jelas al-Naskh atau petunjuk yang berdiri di atas nas al-Shari ${ }^{\text {‘ }}$ secara jelas. Selain daripada perkara tersebut, maka tidak berani sama sekali untuk menyatakan al-Naskh terhadap nas syariat, bahkan dituntut kaedah-kaedah al-Jam ' antara hadithhadith dengan isyarat-isyarat syarak". ${ }^{59}$

Kenyataan al-Laknāwī ini jelas menunjukkan bahawa terdapat perbezaan dalam penentuan al-Naskh. Dimana penggunaan istilah 'al-Naskh Haqiqah' ini merujuk kepada alNaskh al-Sarīh yang memberi implikasi dalam tertib manhaj penyelesaian Mukhtalif al-Hadìth. Perbezaan al-Naskh al-Ṣarịh dan al-Naskh Ghayr al-Șarīh ini turut dipersetujui oleh para pengkaji hadith kontemporari. ${ }^{60}$

58 Bahkan para fuqahā' seperti 'Abd al-Karīm Zaydān turut membahagikan sebagaimana Sharaf al-Quḍāh dengan istilah al-Naskh al-Sarīh (jelas) dan al-Naskh al-Dimni (tersirat). Lihat 'Abd al-Karīm Zaydān, Al-Wājīz fì Ușūl al-Fiqh (Beirut: Muassasah al-Risālah Nashirun, 2013), 307.

59 Muhammad 'Abd al-Hayy al-Laknāwī, Al-Ajwibah al-Faḍilah li al-As'ilah al-'Ashrah al-Kamilah, ed. 'Abd al-Faț̣āḥ Abū Ghuḍāh (Beirut: Maktab alMatbū'at al-Islāmiyyah, 1984),193.

60 Al-Dusārī, Qawā 'id Raf' al-Ikhtilāf, 322. Sharaf al-Quḍāh, 'Ilm Mukhtalif al-Hadīth, 16. Al-Laknāwī, Al-Ajwibah al-Faḍ̂lah,183-184. Mājid bin 'Alī al-Ghāmidī, "Mukhtalif al-Hadīth 'Inda al-Qāḍ̄ 'Iyāḍ min Khilal Kitābihi "Ikmal al-Mu'lim": Jam‘an wa Dirāsah Muqāranah" (disertasi, Jāmi‘ah Umm al-Qurā, Arab Saudi, 2015), 65. Jawwad Muhammad Aḥmad Darwish, "Manhaj Ibn Hajar fī Mukhtalif al-Hadīth min Khilal Kitābihi Fath al-Bārī Sharh Șaḥ̄h al-Bukhārī: "Ard wa Taḥlīl”" (disertasi, al-Jāmi'ah alIslamiyyah, Gaza, 2001), 62. 'Abdullah Murtaji; 'Abd Allāh Mușțafā Sa‘̄id, "Manhaj al-Imām al-Bukhārī fì Mukhtalif al-Ḥadīth fì Șạ̣ịhihi wa alMuwāzanah Baynahu wa Bayna Manhaj al-Imām al-Tirmidhī fì Mukhtalif al-Ḥadīth fì Jami'ihi”' (tesis kedoktoran, Jāmi'ah al-Qur'ān al-Karīm wa al'Ulūm li al-Islāmiyyah, Sudan, 2000), 71. Hāakimah Ḥāfiz̄i, Mukhtalif alHadīth: Mudhazzikah Muqaddimah li Talabah al-Sanah al-Thālithah (Algeria: Jāmi'ah al-Amir 'Abd al-Qādir li al-'Ulūm al-Islāmiyyah, 2013), 65. 'Abd Allāh bin Jābir al-Hammādī, Mukhtalif al-Hadīth 'Inda al-Imām Ibn 'Abd al-Barr: 'Ard wa Dirāsah (Riyadh: Dār Kunūz Ishbiliya, 2012), 149. 
Berdasarkan kenyataan al-Laknāwī di atas juga, beliau menjelaskan beberapa kriteria yang melayakkan al-Naskh itu dikategorikan sebagai al-Naskh al-Sarīh, antaranya ialah terdapat hadith, bukti atau petunjuk yang jelas yang menunjukkan berlakunya al-Naskh. Secara ringkasnya, al-Naskh yang dikategorikan sebagai al-Naskh al-Sarīh adalah sebagaimana berikut:

i) Kenyataan jelas daripada Rasulullah SAW.

Hal ini bermaksud Rasulullah SAW sendiri yang menyatakan secara jelas hadith-hadith yang dimansuhkan dengan hadith-hadith yang lain. Ia merupakan kaedah yang paling kuat mengetahui alNaskh. ${ }^{61}$ Hal ini merupakan satu kesepakatan seluruh para ulama dan tiada sesiapa pun yang menyanggahinya. ${ }^{62}$ Antara bentuk kenyataan jelas daripada Rasulullah SAW bahawa sesuatu hadith itu Mansūkh ialah Baginda menyatakan: "Hadith ini mansuhkan hadith ini" atau apa-apa ucapan yang menggambarkan makna ini. ${ }^{63}$ ii) Kenyataan secara jelas daripada sahabat.

Hal ini bermaksud para sahabat menyatakan secara jelas terhadap hadith yang mengalami al-Naskh dan menunjukkan bukti hadith yang menjadi al-Nāsikh. Seumpama para sahabat berkata: "Hadith ini telah memansuhkan hadith ini", ${ }^{64}$ "Baginda memberikan

61 Ibn Hajar, Nuzhah al-Naẓar, 78. Al-Dusārī, Qawā 'id Raf‘ al-Ikhtilāf, 322.

62 Al-Khātib al-Baghdādī, Al-Fāqih wa al-Mutafaqqih, 133. Ibn Șalāḥ, Muqaddimah Ibn al-Ṣalāḥ, 322. Al-Nawāwī, Irshād Țullab al-Haqā'iq, 185. Abū Muḥammad 'Alī bin Aḥmad bin Sa'id bin Hazm Ibn Hazm, Al-Iḥkām fì Ușūl al-Aḥkām, ed. Aḥmad Muḥammad Shākir (Beirut: Dār al-Āfāq alJadīdah, t.t.) 4:84. Abū Isḥāq Ibrāhīm bin 'Alī al-Shirāzī, al-Lumā' fì Ușūl al-Fiqh (Beirut: Dār al-Kutub al-'Ilmiyyah, 2014), 61. Al-Laknāwī, AlAjwibah al-Faḍīlah, 190. Al-Dusārī, Qawā 'id Raf' al-Ikhtilāf, 322. 'Abd alMājid Muhammad Ismā'̄̄l al-Susiwah, Manhaj al-Tawfìq wa al-Tarjīh Bayna Mukhtalif al-Hadīth wa Athāruhu fì al-Fiqh al-Islāmī (Beirut: Dār alDhakha'ir, 1997), 301. Nafidh Hammad, Mukhtalif al-Hadīth, 266-267.

63 Al-Laknāwī, Al-Ajwibah al-Faḍ̄lah, 190. Murtaḍā 'Alī bin Muhammad alDaghistani, Al-Madkhal ilā Ușūl al-Imām al-Shāfi 'ì min Khilal Tuhfah alMuhtāj bi Sharh al-Manhaj (Damsyik: al-Mashrīq li al-Kitāb, 2008), 2:312. Wahbah al-Zuhaylī, Ușūl al-Fiqh al-Islāmī (Damsyik: Dār al-Fikr, 2009), 286.

64 Sebahagian ulama berpandangan bahawa ucapan "Hadith ini Nāsikh" tidak dianggap al-Naskh disebabkan ia merupakan ijtihad. Namun ahli hadith menetapkan ia merupakan al-Naskh. Zaynuddin berkata: "Pandangan yang dikemukakan oleh ahli hadith adalah lebih jelas dan lebih masyhur kerana al-Naskh tidak berlaku secara ijtihad”. Lihat Muhammad bin Ismā'īl al- 
rukhsah pada hadith ini, kemudian melarangnya" atau ucapan yang seumpamanya. ${ }^{65}$ Kaedah ini diterima oleh para ulama disebabkan tiada ruang ijtihad dalam menentukan perkara ini. ${ }^{66}$ Oleh yang demikian, al-Naskh berdasarkan kaedah ini adalah dibenarkan dan diterima, ${ }^{67}$ bahkan menurut al-Laknawi ia merupakan pandangan yang paling benar dan tepat. ${ }^{68}$

iii) Kenyataan al-ijma ‘

Hal ini bermaksud para ulama ijma ' berlakunya al-Naskh terhadap salah satu hadith dengan hadith yang lain. Bahkan lebih utama lagi sekiranya para Sahabat yang mengeluarkan kenyataan ijma ' seperti menyatakan: "Hadith ini Nāsikh" dan "Hadith ini alMansukh" tanpa seorang Sahabat pun yang membantahnya. ${ }^{69}$

Hal ini berbeza dengan al-Naskh Ghayr al-Sarīh kerana ia diputuskan berdasarkan kemungkinan-kemungkinan yang tidak pasti (ihtimaliyyah) dan tidak ditetapkan melalui nas. ${ }^{70}$ Dalam keadaan ini, para muhaddithīn perlu menyelidiki masa munculnya kedua-dua hadith tersebut. Sekiranya ditemui dan salah satunya lebih terdahulu daripada yang lainnya, maka mereka berpegang dengan hadith yang terkemudian sebagai Nāsikh dan meninggalkan hadith yang terdahulu sebagai Mansūkh. ${ }^{71}$

Șan'ānī, Tawḍ̄hh al-Afkār li Ma 'ānī Tanqih al-Anzar, ed. Muhammad Mahy al-Dīn 'Abd al-Hāmid (Madinah: al-Maktabah al-Salāfiyyah, 1947), 2: 238. Jalāl al-Dīn 'Abd al-Rahman bin Abī Bakr al-Suyūtī, Al-Itqān fì 'Ulūm alQur'ān, ed. Muhammad Abū al-Faḍl Ibrāhīm (Kaherah: al-Hay'ah alMișriyyah al-'Āmmah, 1974), 3: 81. Al-Susiwah, Manhaj al-Tawfiq wa alTarjīh, 301. Al-Dusārī, Qawā 'id Raf‘ al-Ikhtilāf, 327.

66 Al-'Irāqī, Sharh al-Tabșirah wa al-Tadhkīrah, 2: 99. Al-Ṣan'ānī, Tawdīh alAfkēr, 2: 238. Al-Laknāwī, Al-Ajwibah al-Faḍ̄lah, 192. Nafidh Hammad, Manhaj al-Imām al-Shāfi 'ì fì Nāsikh al-Hadīth wa Mansūkhihi, 208. Wahbah al-Zuhaylī, Ușūl al-Fiqh al-Islāmī, 2:287.

67 Ibn Hazm, Al-Iḥkām fì Ușūl al-Aḥkām, 4:84. Al-Laknāwī, Al-Ajwibah alFaḍilah, 190. Al-Susiwah, Manhaj al-Tawfìq wa al-Tarjīh, 302. Al-Shirāzī, Al-Lumā' fì Ușūl al-Fiqh, 61.

68 Al-Laknāwī, Al-Ajwibah al-Faḍ̄lah, 192.

69 Al-Susiwah, Manhaj al-Tawfiq wa al-Tarjīh, 304

70 Al-Susiwah, Manhaj al-Tawfiq wa al-Tarjīh, 122

71 'Abd al-Raḥman bin 'Abd Allāh al-Sha'alan, Ușūl Fiqh al-Imām Mālik Adillatuh al-Naqliyyah (Arab Saudi: Jāmi'ah al-Imām Muhammad bin Sa'ūd al-Islāmiyyah, 2002), 2:750. Abū Bakr Muhammad bin Mūsā bin 'Uthmān al-Hāzimī, Al-I'tibar fì al-Nāsikh wa al-Mansūkh min al-Athār, (Hyderabad: Dai'rah al-Ma'ārif al-'Uthmāniyyah, 1938), 8. Ibn Șalāḥ, Muqaddimah Ibn al-Salāh, 257. Al-Nawāwī, Irshād Țullab al-Haqū 'iq, 190. 
Pelbagai kaedah yang digunakan bagi mengenalpasti masa hadith terakhir antara hadith-hadith yang bercanggah. Penetapan berdasarkan tarikh sahaja yang disepakati oleh muhaddithin, manakala penetapan selainnya merupakan kaedah yang diperselisihkan muhaddithīn dan para pengkaji hadith. ${ }^{72}$ Terdapat empat kaedah yang diaplikasikan untuk mengetahui penetapan masa hadith terakhir daripada dua hadith sebagaimana berikut:

a. Kenyataan jelas tentang tarikh kedua-dua hadith.

Kaedah ini dapat menentukan sesebuah hadith berlaku pada waktu yang terakhir berdasarkan tarikh kedua-dua hadith. Kaedah ini berdasarkan prinsip yang dikemukakan oleh al-Shāfi' $\overline{1}$ sebagaimana berikut:

"Tidak dapat menentukan al-Nāsikh wa al-Mansukh melainkan dengan khabar daripada Rasulullah SAW, atau ucapan atau waktu yang menunjukkan salah satunya yang terakhir, lalu diketahui bahawa yang akhir itu adalah alNāsikh." 73

Berdasarkan kenyataan tersebut, para muhaddithin perlu meneliti waktu berlaku kedua-dua hadith tersebut. Sekiranya

Al-'Irāqī, Al-Tabșirah wa al-Tadzkīrah, 2:110. Ibn al-Mulaqqīn, AlMughnī', 2:482. Ibn Hajar, Nuzhah al-Nazar, 77. Al-Sakhāwī, Fatḥ alMughìth, 4:70. Muhammad Abū al-Layth, 'Ulüm al-Hadìth, 309.

72 Aḥmad bin Muḥammad al-Azdī al-Ṭaḥāwī, Sharḥ Mushkil al-Athār, ed. Syu'ayb al-Arnauth (Beirut: Muassasah al-Risālah, 1994), 2: 294, 2: 406, 14: 316, 12: 387-389. Hasan bin 'Abd al-Ḥāmid bin 'Abd al-Ḥākim Bukhārī, "Manhaj al-Imām al-Ṭahāwī fī Daf" al-Ta'arruḍ Bayna al-Nușūṣ al-Shar'iyyah min Khilal Kitābihi Sharḥ Mushkil al-Athār" (disertasi, Jāmi'ah Umm al-Qura, Mekah, 2001), 245-262. Munīrah bint 'Abd Allāh bin Șālih al-'Iskir, "Mukhtalif al-Ḥadīth Inda al-Qādī Ibn al-'Arābī fì Kitābihi al-Masālik fī Sharḥ Muwaț̣ā’ Mālik: Jam‘ wa Dirāsah”, 563-636. 'Abd Allāh Murtajī, Manhaj al-Imām al-Bukhārī fì Mukhtalif al-Hadīth, 204-206. Jawwad Muḥmmad Ahmad Darwish, Manhaj Ibn Hajar fi Mukhtalif al-Hadìth, 135-139. Samīrah Ibrāhīm Hamdan Ikhziq, "Manhaj al-'Aynī fī Mukhtalif al-Ḥadīth: Dirāsah Tațbiqiyyah 'alā Kitābihi 'Umdah al-Qārī Sharḥ SSah̄ịh al-Bukhārı̄” (disertasi, al-Jāmi'ah al-Islāmiyyah Gaza, Palestin, 2013), 111. Ibn Șalāḥ, Muqaddimah Ibn al-Salāh, 256-257. AlKhāțib al-Baghdādī, Al-Fāqih wa al-Mutafaqqih, 126-134. Al-Dusārī, Qawā 'id Raf" al-Ikhtilāf, 317-352. Al-Susiwah, Manhaj al-Tawfiq wa alTarjīh, 300-306. Nafidh Hammad, Mukhtalif al-Hadīth, 266-279. Usāmah bin 'Abd Allāh Khayyāț, Mukhatalif al-Hadìth, 183-201. Abū al-Layth, 'Ulüm al-Hadith, 293-294.

73 Al-Shāfi'‘ì, Ikhtilāf al-Hadìth,40-41. 
ditemui pada kedua-duanya atau salah satunya petunjuk yang menunjukkan salah satunya lebih terdahulu berbanding yang lain, maka hadith yang terdahulu dianggap sebagai Mansukh dan hadith yang terakhir sebagai Nāsikh. ${ }^{74}$ Seumpama sebuah hadith berlaku pada peperangan uhud dan hadith yang lain pada Fath al-Makkah, maka yang terakhir adalah pada Fath al-Makkah yang menjadi Nāsikh berbanding hadith yang terdahulu yang berlaku pada peperangan uhud. ${ }^{75}$

Walaupun demikian, pengetahuan tarikh sesuatu hadith berlaku tidak semestinya menatijahkan sesuatu hadith terdahulu merupakan al-Mansūkh dan hadith yang akhir merupakan alNāsikh. Hal ini demikian kerana semata-mata tarikh tidak mampu mengesahkan secara yakin, sebaliknya ia memerlukan bukti-bukti sokongan yang lain yang mampu mengukuhkan keyakinan bahawa benar-benar berlakunya al-Naskh. ${ }^{76}$

b. Kenyataan jelas para sahabat tentang hadith terakhir antara kedua-dua hadith.

Penentuan sesebuah hadith berlaku pada waktu yang terakhir dapat dikesan berdasarkan kenyataan seseorang sahabat. Hal ini bermaksud terdapat riwayat daripada sahabat yang menyatakan bahawa salah satu hadith yang bercanggah lebih terdahulu berbanding hadith yang lain sehingga dapat difahami bahawa hadith yang terakhir telah memansuhkan hadith yang terdahulu. ${ }^{77}$ Antara kenyataan mereka ialah "hadith ini merupakan yang terakhir bagi dua perkara ini". ${ }^{78}$

Walaupun demikian, ungkapan seseorang sahabat "hadith ini merupakan yang terakhir bagi dua perkara ini" tidak sewajibnya menunjukkan bahawa hadith yang terdahulu adalah mansukh.

74 Al-Susiwah, Manhaj al-Tawfiq wa al-Tarjīh, 303. Jawwad Darwish, Manhaj Ibn Hajar fì Mukhtalif al-Hadìth, 137.

75 Al-Dusārī, Qawā 'id Raf' al-Ikhtilāf, 330.

76 Bahkan menurut al-Laknāwī, ini merupakan pandangan muktamad. Lihat Al-Laknāwī, Al-Ajwibah al-Faḍ̄lah, 192. Al-Ḥāzīmī, Al-I'tibār fì al-Nāsikh wa al-Mansūkh, 7. Ibrāhīm bin Mūsā bin Muhammad al-Ghirnatī, AlMuwāfaqāt, ed. Mashhur bin Hasan 'Alī Salmān (Madinah: Dār Ibn 'Affān, 1997), 3:339-340.

77 Al-Dusārī, Qawā 'id Raf' al-Ikhtilāf, 338.

78 Al-Suyūțī, Al-Itqān fì 'Ulūm al-Qur'ān, 3: 81. Al-Susiwah, Manhaj alTawfìq wa al-Tarjīh, 301. Al-Dusārī, Qawā id Raf" al-Ikhtilāf, 327. 
Justeru, pandangan yang menyatakan bahawa perkara yang akhir bagi dua perkara daripada Rasulullah SAW ialah perkara yang diamalkan, maka ia merupakan al-Nāsikh yang jelas, maka ia memerlukan kepada penilaian secara lebih terperinci. ${ }^{79}$

c. Bukti jelas salah satu hadith adalah hadith terakhir, sekalipun tidak diketahui tarikh hadith lain.

Penentuan al-Naskh ini berdasarkan hadith terakhir yang dapat dikenalpasti secara yakin berbanding hadith-hadith bercanggah yang lain. Menurut al-Dusārī, hal ini dapat dikenal pasti melalui perawi hadith pertama meninggal dunia sebelum Islamnya perawi yang kedua atau sebelum dia meriwayatkan hadith atau salah seseorang perawi hadith menyebutkan sesuatu daripada Nabi Muhammad SAW pada ketika Baginda sakit yang membawa kepada kematian. Oleh yang demikian, situasi-situasi tersebut merupakan satu bukti yang yakin bahawa hadith tersebut merupakan hadith yang terakhir. ${ }^{80}$

Penentuan ini memerlukan penelitian yang mendalam daripada para muhaddithīn dalam memastikan secara pasti manamana hadith yang berlaku pada masa yang terakhir. Penentuan terhadap hadith-hadith yang bercanggah juga berhadapan dengan pelbagai kemungkinan sebagaimana yang telah pengkaji nyatakan pada penentuan kedua sebelum ini.

iv. Kelewatan sahabat memeluk Islam.

Penentuan salah satu hadith merupakan hadith yang terdahulu dan yang lainnya merupakan hadith yang terakhir ialah melalui tarikh kelewatan seseorang sahabat memeluk Islam. Oleh itu, salah seorang perawi yang memeluk Islam lebih awal meriwayatkan sebuah hadith dan seorang perawi yang memeluk agama Islam lebih lewat daripadanya juga meriwayatkan sebuah hadith yang mana kandungannya saling bercanggah. Dalam keadaan ini, hadith yang diriwayatkan oleh perawi yang lebih lewat memeluk Islam

79 Al-Laknāwī, Al-Ajwibah al-Faḍ̄lah, 193-194. 'Abd al-Wahhāb bin Aḥmad al-Sha'rān̄̄, Kashf al-Ghummah 'an Jami' al-Ummah (Mesir: al-Ṭab'ah alMaymanah, 1900), 1: 6-7.

80 Al-Dusārī, Qawā 'id Raf' al-Ikhtilāf, 340. 
sebagai al-Nāsikh dan hadith yang diriwayatkan oleh perawi yang lebih awal memeluk Islam sebagai al-Mansükh. ${ }^{81}$

Walau bagaimanapun, para muhaddithin berbeza pandangan dalam penentuan al-Naskh berdasarkan kaedah ini. Terdapat golongan yang mengiktiraf penentuan ini ${ }^{82}$ dan golongan yang tidak mengiktirafnya kerana terdapat beberapa andaian seumpama perawi yang terdahulu mendengar selepas perawi yang lebih lewat memeluk Islam dan kemungkinan perawi yang lebih lewat memeluk Islam telah mendengar daripada sahabat yang lain yang lebih awal daripada perawi yang awal memeluk Islam tersebut atau perawi yang lebih lewat itu meriwayatkan secara Mursal $^{83}$

Berdasarkan kedua-dua pandangan di atas, pengkaji merumuskan bahawa aplikasi ini tidak boleh diterima secara mutlak, sebaliknya memerlukan bukti-bukti sokongan bagi menghilangkan kemungkinan yang menafikan al-Naskh. Manakala pandangan kedua pula tidak menolak secara total kaedah ini menjadi salah satu bukti al-Naskh, namun bukti ini memerlukan kepada bukti sokongan lain tatkala mengesahkan sesuatu hadith dimansuhkan. Oleh kerana itu, al-Sakhāwī menimbulkan beberapa andaian yang perlu dikemukakan secara yakin bagi mengesahkan berlakunya al-Naskh terhadap sesuatu hadith. Demikian juga dengan pandangan Ibn Hajar yang menegaskan bahawa bukti ini tidak semestinya menunjukkan berlakunya al-Naskh, bahkan memerlukan bukti sokongan yang lain. Oleh yang demikian, penentuan ini tidak boleh ditolak secara total disebabkan muhaddithīn daripada kalangan mutaqaddimin turut mengaplikasikan aplikasi ini pada sebahagian permasalah yang diperselisihkan. ${ }^{84}$

81 Al-Susiwah, Manhaj al-Tawfíq wa al-Tarjīh Bayna Mukhtalif al-Hadìth wa Athāruhu fì al-Fiqh al-Islāmī, 307.

82 Al-Ṭahāwī mengaplikasikan dalam karya beliau tatkala membincangkan permasalahan sapu di atas dua khuf dan al-Nawāwī dalam wudhuk disebabkan menyentuh zakar. Lihat, al-Ṭahāwī, Sharh Mushkil al-Athār, 6: 289-299. Al-Nawāwī, Majmū' Sharh al-Muhadhdhab (Kaherah: Dār al-Fikr, t.t.), 2:43.

83 Al-Shawkānī, Irshād al-Fuhūl, 2:85. Al-Susiwah, Manhaj al-Tawfìq wa alTarjīh, 307.

84 Antaranya ialah al-Bukhārī dan Muslim dalam permasalahan solat dengan menyapu ke atas dua khuf. Al-Bukhārī menyatakan: "Ibrāhīm al-Taymiberkata: Sesungguhnya beliau kagum dengan mereka kerana Jarīr merupakan antara yang terakhir yang memeluk Islam”. Demikian juga 


\section{[Kedua] Tertib al-Jam', al-Naskh al-Șarīḥ dan al-Naskh Ghayr al-Ṣarīḥ dalam Penyelesaian Mukhtalif al-Ḥadīth.}

Penyelesaian Mukhtalif al-Hadith berdasarkan manhaj al-Jam ‘ merupakan manhaj yang paling diberi perhatian oleh para muhaddithīn. ${ }^{85} \mathrm{Al}-\mathrm{Hād} \overline{1}$ Rushu berkata:

"Sesiapa yang memerhatikan manhaj-manhaj para muhaddithin, pasti akan terserlah kepada kita bahawa para muhaddithin sangat bersungguh-sungguh mengaplikasikan alJam' antara Mukhtalif al-Hadìth. Mereka lebih banyak mengaplikasikannya berbanding kaedah al-Tarjīh dan alNaskh". ${ }^{86}$

Bahkan Ibn 'Abd al-Barr menegaskan bahawa inilah tanggungjawab muhaddithīn untuk mengamalkan kedua-dua hadith sedaya upaya. ${ }^{87}$ Lebih daripada itu, Ibn Khuzaymah menyatakan bahawa praktikal ini bukan sahaja tertumpu kepada muhaddithīn sahaja, bahkan merangkumi dalam semua bidang ilmu. ${ }^{88}$

Muslim berkata: "Al-A'mash berkata: Ibrahim berkata: Sesungguhnya hadith ini sungguh mengkagumkan kerana Jarir memeluk Islam selepas penurunan Surah al-Mā'idah". Lihat hadith riwayat al-Bukhārī, Kitāb alȘalah, Bāb al-Ṣalāh fī al-Khifaf, no. Hadith: 374. 2: 141. Muslim, Kitab alȚaharah, Bab al-Mash 'alā al-Khuffayn, no. Hadith: 401, 2: 97.

85 Hal ini dapat ditemui berdasarkan pandangan dan praktikal para muhaddithīn di dalam karya-karya beliau antaranya ialah Mālik, al-Shāfi‘‘̄, Yaḥyā bin Sa‘īd al-Qaț̣̄ān, Ibn Khuzaymah, Ibn Daqīq al-'Id, Ibn Hajar, Ibn 'Abd al-Barr dan lain-lain. Lihat al-Sha'alan, Ușūl Fiqh al-Imām Mālik Adillatuh al-Naqliyyah, 743-761. Al-Shāfi'î, Ikhtilaf al-Hadīth, 40. Șāliḥ bin Aḥmad bin Hanbal, Masā'il al-Imām Aḥmad bin Hanbal - Riwayat Ibnihi Abī al-Fạ̣l Șālih, ed. TTarīq bin 'Iwad Allāh bin Muhammad (Riyadh: Dār al-Wațan, 1999), 76 dan 196-197. Muḥammad bin Isḥāq al-Naysabūrī Ibn Khuzaymah, Sạhīh Ibn Khuzaymah, ed. Muḥammad Mușțafā al-A'zamī, (Beirut: al-Maktab al-Islāmī, 1970), 2:250. Ibn Daqīq al-'Id; Muḥammad bin 'Alī bin Wahab, Ihkām al-Aḥkam Sharh 'Umdah al-Aḥkām, ed. Muștafā Shaykh Mușțafā (Beirut: Muassasah al-Risālah, 2005), 1:83. Ibn Ḥajar, Fath al-Bārī, 2:451. Ibn 'Abd al-Barr; Abū 'Amrū Yūsuf bin 'Abd Allāh, AlTamhīd limā fì al-Muwattē' min al-Ma 'āñ̄ wa al-Asānid, ed. Muștafa bin Aḥmad al-'Alawī dan Muhammad 'Abd al-Kabīr al-Bakrī (Maghribi: Wizārah 'Umūm al-Awqāf wa al-Shu'un al-Islāmiyyah, 1966), 4:165.

86 Al-Hādī Rushu, Mukhtalif al-Hadìth wa Juhūd al-Muhaddithīn fìh, 128

87 Ibn 'Abd al-Barr, Al-Tamhīd limā fi al-Muwaț̣̄' , 4:165.

88 Beliau berkata: 
Keutamaan manhaj ini berbanding manhaj yang lain dikuatkan di atas dasar praktikal ditunjukkan oleh Rasulullah SAW seumpama hadith pemakaian kain sutera sebagaimana berikut:

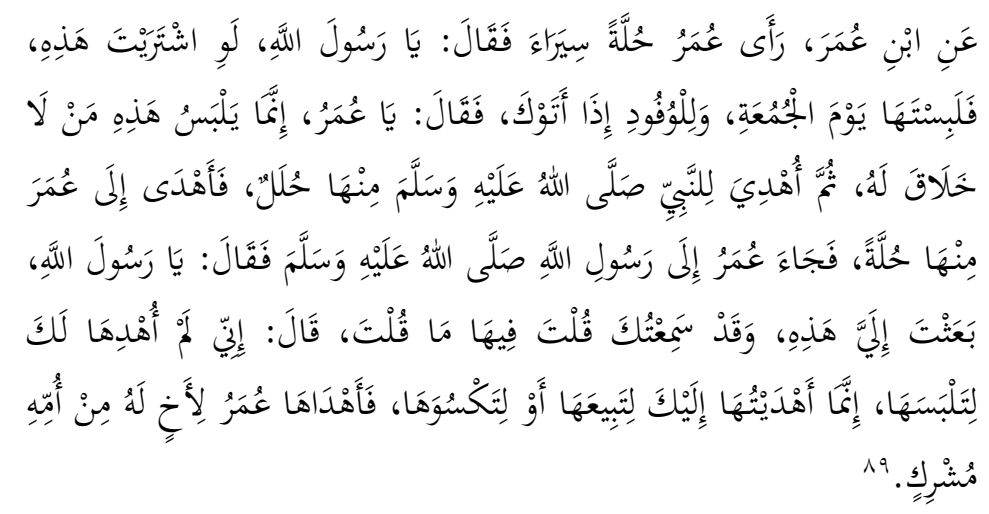

Terjemahan: Diriwayatkan daripada Ibn 'Umar. 'Umar melihat satu pakaian sutera, lantas berkata: "Wahai Rasulullah, sekiranya kamu membeli pakaian ini, lalu kamu memakainya pada hari Jumaat dan menyambut delegasi luar yang datang kepada kamu". Maka Rasulullah SAW bersabda: "Wahai Umar, seseorang yang memakai pakaian sutera merupakan golongan yang tidak mendapatkan bahagian (pada hari kiamat)". Kemudian Nabi Muhammad SAW dihadiahkan beberapa helai pakaian sutera. Lalu Baginda menghadiahkan sehelai pakaian tersebut kepada 'Umar. Lantas 'Umar pergi kepada Rasulullah SAW, lalu berkata: "Wahai Rasulullah, kenapa kamu berikan pakaian ini kepada saya, sedangkan saya telah mendengar kata-kata kamu tentang pakaian ini sebagaimana yang telah kamu nyatakan tadi?". Rasulullah SAW menjawab: "Sesungguhnya saya tidak menghadiahkan pakaian itu untuk kamu agar kamu memakainya, sebaliknya saya menghadiahkannya untuk kamu agar kamu

"Inilah mazhab kami dalam semua bidang ilmu: iaitu setiap dua hadith harus disatukan maknanya. Tidak harus diucapkan bahawa kedua-duanya bercanggah lagi berlawanan".

Lihat, Ibn Khuzaymah, Șahīh Ibn Khuzaymah, 2:250.

89 Hadith riwayat al-Bukhārī, Kitab al-Jumu'ah, Bab Yalbas Aḥsān ma Yajīi, no. Hadith: 837, 3:403. Muslim, Kitāb al-Libās wa al-Zīnah, Bab Taḥrīm Isti'mal Ina' al-Dhahab wa al-Fiḍdah..., no. Hadith: 3851. 10:407. 
menjualkannya atau kamu memberikan pakaian tersebut". Maka 'Umar pun menghadiahkan pakaian itu kepada saudaranya daripada ibunya yang musyrik".

Menurut al-Khāṭib al-Baghdādī, hadith ini menjadi sandaran yang kuat dimana Rasulullah SAW sendiri secara praktikal mengajar para sahabat agar mengambil dan mengamalkan kesemua hadith. ${ }^{90}$ Oleh yang demikian, keutamaan terhadap manhaj ini sememangnya menjadi tanggungjawab para muhaddithin agar semua hadith mampu diamalkan secara keseluruhannya apabila mempu melakukannya.

Sekalipun manhaj al-Jam ' secara dasarnya didahulukan berbanding manhaj al-Naskh, namun kekuatan daripada sudut pendalilan pada manhaj al-Naskh al-Șarīh adalah lebih kuat. Hal ini menjadi faktor manhaj al-Naskh al-Șarịh mesti didahulukan berbanding al-Jam'. Menurut al-Dusārī, antara sebab manhaj ini mesti didahulukan disebabkan manhaj ini tidak memerlukan ijtihad dan tidak memerlukan penelitian secara mendalam sebagaimana manhaj-manhaj yang lain. Sebaliknya kewajipan seseorang pengkaji hanya perlu memastikan kesahihan riwawat alNaskh dalam menetapkan al-Naskh yang berlaku pada sesuatu hadith. ${ }^{91}$ Dalam keadaan ini, manhaj al-Naskh al-Sarīh merupakan pengamalan yang sahih terhadap nas ${ }^{92}$ dan pengamalan terhadap sesuatu yang pasti. ${ }^{93}$ Oleh yang demikian, tiada lagi keperluan untuk mengaplikasikan manhaj al-Jam ' dan al-Tarjih ${ }^{94}$ terhadap hadith-hadith yang bercanggah kerana ia akan menatijahkan penyatuan antara dalil dan bukan dalil, ${ }^{95}$ sedangkan tiada lagi ruang ijtihad apabila terdapat nas yang jelas dalam sesuatu permasalahan. ${ }^{96}$ Oleh itu, menjadi satu kesalahan yang nyata sekiranya seseorang pengkaji tetap mahu mengaplikasikan manhaj al-Jam ' sedangkan di sana terdapat bukti jelas bahawa salah satu

\footnotetext{
$90 \quad$ Al-Khātịib al-Baghdādī, Al-Fāqih wa al-Mutafaqqīh, 217.

Al-Dusārī, Qawā 'id Raf' al-Ikhtilāf, 322.

Mājid bin 'Alī al-Ghāmidī, Mukhtalif al-Hadìth 'Inda al-Qāḍ̄ 'Iyāḍ, 65.

Jawwad Muḥammad, Manhaj Ibn Hajar fì Mukhtalif al-Hadìth, 62.

'Abd Allāh al-Hammādī, Mukhtalif al-Hadīth 'Ind al-Imām Ibn 'Abd alBarr, 149.

95 'Abd Allāh Murtajī, Manhaj al-Imām al-Bukhārī wa al-Tirmidhī fì Mukhtalif al-Hadìth, 71.

96 'Abd al-Karīm Zaydan, Al-Wajiz fì Sharh al-Qawā' 'id al-Fiqhiyyah (Beirut: Muassasah al-Risālah Nashirun, 2014), 37.
} 
hadith tersebut telah dimansuhkan dan digugurkan pengamalannya.

Walaupun manhaj al-Naskh perlu didahulukan berbanding manhaj al-Jam ', namun ia hanya dikhususkan kepada al-Naskh alSarīh sahaja, bukannya secara mutlak. Oleh itu, terdapat pemisahan antara al-Naskh al-Șarīh dan al-Naskh Ghayr al-Ṣarīh tatkala mengaplikasikan manhaj Mukhtalif al-Hadith. Hal inilah yang menjadi punca perbezaan antara muhaddithin dan al-ahnaf. Dimana muhaddithin hanya mendahulukan manhaj al-Naskh alSarīh berbanding al-Jam ' ${ }^{97}$ sebaliknya al-ahnaf mendahulukan alNaskh secara mutlak berbanding manhaj al-Jam ' dan al-Tarjī ${ }^{98}$ Bantahan terhadap golongan al-ahnaf jelas dikemukakan oleh para muhaddithin daripada kalangan al-ahnaf yang tidak sependapat dengan mazhab mereka berhubung mendahulukan al-Naskh berbanding al-Jam ' secara mutlak. ${ }^{99}$

Adapun pandangan muhaddithin yang mendahulukan al-Jam ‘ berbanding al-Naskh dan al-Tarjīh sebagaimana dalam karyakarya Muștalah al-Hadīth ialah mendahulukan al-Jam ' berbanding al-Naskh Ghayr al-Sarīh yang ditentukan berdasarkan tarikh. ${ }^{100}$ Sebaliknya, apabila didapati secara jelas sesuatu hadith terangkatnya hukum secara al-Naskh secara pasti iaitu al-Naskh al-Ṣarịh, maka ia mesti didahulukan berbanding al-Jam ' dan alTarjih. Pandangan ini merupakan kesepakatan muhaddithīn dan tiada ulama pun yang mengingkarinya. ${ }^{101}$ Bahkan inilah

97 Sharaf al-Quḍāh, 'Ilm Mukhtalif al-Hadìth, 16.

98 Ibin Nizāām al-Dīn; 'Abd al-'Alī Muhammad bin Niz̄ām al-Dīn al-Sahalāwī, Fawātih̆ al-Rahamut bi Sharh Musallam al-Thubut (Beirut: Dār al-Kutub al'Ilmiyyah, 2002), 2:189.Abū 'Abd Allāh Shams al-Dīn Muhammad bin Muhammad Amīr Hāj, Al-Taqrīr wa al-Tahbir (Beirut: Dār al-Kutub al'Ilmiyyah, 1983), 3:3-4. Muḥammad bin Aḥmad Al-Sarakhsī, Uṣūl alSarakhsī (Beirut: Dār al-Ma'rifah, t.t), 2:13.

99 Antaranya ialah al-Ṭahāwī dan al-Laknāwī. Lihat al-Ṭahāwī, Sharḥ Ma'ān̄̄ al-Athār, 3:83. Al-Laknāwī, Al-Ajwibah al-Faḍ̄lah, 183.

100 Al-Dusārī, Qawā 'id Raf' al-Ikhtilāf, 178.

101 Al-Laknāwī, Al-Ajwibah al-Faḍilah,183-184. Al-Dusārī, Qawā 'id Raf' alIkhtilāf, 178. Hakimah Hafizi, Mukhtalif al-Hadīth, 65. 'Abd Allāh alHammādī, Mukhtalif al-Hadìth 'Ind al-Imām Ibn 'Abd al-Barr, 149. Jawwad Muhammad, Manhaj Ibn Hajar fì Mukhtalif al-Hadìth, 62. 
pandangan yang telah dikemukakan oleh muhaddithīn daripada pelbagai generasi. ${ }^{102}$

\section{Penutup}

Berdasarkan analisis yang dikemukakan di atas, pengkaji menyimpulkan bahawa tertib manhaj penyelesaian Mukhtalif alHadīth yang dikemukakan oleh Sharaf al-Quḍāh tidak bercanggah dengan pandangan dan aplikasi para muhaddithìn, sekalipun karya-karya Muștalah al-Hadith tidak menyusun tertib sebagaimana yang disusun oleh Sharaf al-Quḍāh. Namun pada hakikatnya susunan tertib tersebut dipersetujui oleh seluruh para muhaddithìn dan tiadapun muhaddithìn yang membantahnya.

Oleh yang demikian, pembahagian al-Naskh kepada al-Naskh al-Sarīh dan al-Naskh Ghayr al-Ṣarīh merupakan pembahagian yang tepat disebabkan faktor penentuan al-Naskh adalah berbeza daripada segi kekuatannya. Faktor kekuatan dalam penentuan alNaskh ini penting agar penentuan tertib manhaj dapat disusun berdasarkan kekuatan sesuatu manhaj.

Dalam hal ini, manhaj al-Naskh al-Ṣarīh memiliki kekuatan yang lebih kuat berbanding manhaj yang lain disebabkan manhaj ini berpegang kepada nas yang jelas dalam penentuan al-Naskh, tidak melibatkan ijtihad dan tidak memerlukan penelitian secara mendalam. Oleh itu, manhaj al-Naskh al-Ṣarịh didahulukan berbanding manhaj-manhaj yang lain.

102 Al-Sha'alan, Ușūl Fiqh al-Imām Mālik, 743-761. Al-Shāfi'ī, Ikhtilāf alHadīth, 40. Al-Shāfi '̄i, Al-Umm, 6:419. Al-Ṭahāwī, Sharh Ma'ān̄̄ al-Athār, ed. Muhammad Zuhrī al-Najjār dan Muhammad Sayyīd Jād al-Haq, (Madinah: 'Alam al-Kutub, 1994), 3:83. Abū Sulaymān Hamd bin Muhammad bin Ibrāhīm al-Khatțābī, Ma 'àlim al-Sunan (Halab: al-Maṭba'ah al-'Ilmiyyah, 1932), 5:37. Al-Bayhāq̄î, Al-Khilāfiyyāt Bayna al-Imāmayn alShāfi '̌ wa Abū Hanīfah wa Ashāābih, ed. Mashhūr bin Ḥasan 'Alī Salmān, (Riyadh: Dār al-Sami'i, 1994), 1:329. Ibn 'Abd al-Barr, Al-Tamhīd, 15:307. Al-Nawāwī, Al-Minhaj Sharh Sậ̄ị Muslim, 1:35. Al-Khāṭib al-Baghdādī, Al-Fāqih wa al-Mutafaqqih, 217. Abū Bakr Muḥammad bin Ibrāhīm Ibn alMundhīr, Al-Awsat fì al-Sunan wa al-Ijmā' wa al-Ikhtilāf, ed. Abū Hammād Saghīr Aḥmad (Riyadh: Dār Ṭayyibah, 1985), 2:268. Al-Jazā'irī, Tawjih̆ alNazar, 1:541. Al-Ḥāzimī, Al-I'tibār, 11. Al-Laknāwī, Al-Ajwibah alFaḍilah, 183. Al-'Irāqī, Sharh al-Tabṣirah wa al-Tadhkirah, 2:109. AlSakhāwī, Fath al-Mughīth, 4:67-70. Ibn Hajar, Nuzhah al-Nazar, 79. Muhammad Abū al-Layth, 'Ulūm al-Hadìth, 309. 
Hal ini berbeza dengan manhaj al-Jam ' dan al-Naskh Ghayr al-Sarīh. Dimana kedua-duanya melibatkan ijtihad dan memerlukan penelitian secara mendalam. Namun, manhaj al-Jam didahulukan berbanding manhaj al-Naskh Ghayr al-Sarīh disebabkan petunjuk daripada Rasulullah SAW agar manhaj alJam' didahulukan dan tanggungjawab para ulama termasuklah para muhaddithin untuk mengamalkan kedua-dua hadith sedaya upaya. Keutamaan yang dimiliki oleh manhaj al-Jam' ini tidak dimiliki oleh manhaj al-Naskh Ghayr al-Sarīh menyebabkan manhaj al-Jam' lebih diutamakan. Akhirnya, tertib manhaj penyelesaian Mukhtalif al-Hadìth menurut muhaddithìn ialah alNaskh al-Sarīh, kemudian al-Jam' dan kemudian al-Naskh Ghayr al-Sarīh.

\section{Bibliografi}

'Abd al-Karim Zaydan (2013), Al-Wajiz fi Usul al-Fiqh, (Beirut: Muassasah al-Risalah Nashirun.

'Abd al-Karim Zaydan (2014), Al-Wajiz fi Sharh al-Qawa'id alFiqhiyyah, Beirut: Muassasah al-Risalah Nashirun.

'Abdullah Murtaji, 'Abdullah Mustafa Sa'id (2000), Manhaj alImam al-Bukhari fi Mukhtalif al-Hadith fi Sahihihi wa alMuwazanah Baynahu wa Bayna Manhaj al-Imam alTirmidhi fi Mukhtalif al-Hadith fi Jami ' ihi, tesis kedoktoran, Jami'ah al-Qur'an al-Karim wa al-'Ulum li al-Islamiyyah, Sudan.

Al-'Iraqi, Abu al-Fadl 'Abd al-Rahim bin Husayn (1969), AlTaqyid wa al-Idah Sharh Muqaddimah Ibn al-Salah, ed. 'Abd al-Rahman Muhammad 'Uthman, (Madinah: alMaktabah al-Salafiyyah.

Al-Bayhaqi, Abu Bakr Ahmad bin al-Husayn (1994), AlKhilafiyyat Bayna al-Imamayn al-Shafi' $i$ wa Abu Hanifah wa Ashabih, ed. Mashhur bin Hasan Ali Salman, Riyad: Dar al-Sami'i.

Al-Daghistani, Murtada 'Ali bin Muhammad (2008), Al-Madkhal ila Usul al-Imam al-Shafi 'i min Khilal Tuhfah al-Muhtaj bi Sharh al-Manhaj, Dimashq: al-Mashriq li al-Kitab.

Al-Fayruz Abadi, Muhammad bin Ya'qub (2005), Al-Qamus alMuhit, ed. Muhammad Na'im al-'Arqasusi, Beirut: Muassasah al-Risalah. 
Al-Fayyumi, Ahmad bin Muhammad bin 'Ali (t.t), al-Misbah alMunir fi Gharib al-Sharh al-Kabir li al-Rafi ' $i$, Beirut: alMaktabah al-'Ilmiyyah.

Al-Hadi Rushu (2009), Mukhtalif al-Hadith wa Juhud alMuhaddithin fih: Dirasah Naqdiyyah, Beirut: Dar Ibn Hazm.

Al-Hakim, Abu 'Abd Allah Muhammad bin 'Abd Allah SWT (1977), Ma'rifah 'Ulum al-Hadith, Beirut: Dar al-Kutub al'Ilmiyyah.

Al-Hammadi, 'Abdullah bin Jabir (2012), Mukhtalif al-Hadith 'Ind al-Imam Ibn 'Abd al-Barr: 'Ard wa Dirasah, Riyad: Dar Kunuz Ishbiliya.

Al-Hazimi, Abu Bakr Muhammad bin Musa bin 'Uthman (1359H), Al-I'tibar fi al-Nasikh wa al-Mansukh min alAthar, Haidrabad: Dairah al-Ma'arif al-'Uthmaniyyah.

Al-Jurjani, 'Ali bin Muhammad bin 'Ali al-Zayn al-Sharif (1983), Kitab al-Ta 'rifat, Beirut: Dar al-Kutub al-'Ilmiyyah.

Al-Kattani, Muhammad bin Ja'far (1986), Al-Risalah alMustatrifah li Bayan Mashhur Kutub al-Sunnah alMusannafah, Beirut: Dar al-Bashair al-Islamiyyah.

Al-Khatib al-Baghdadi, Abu Bakr Ahmad bin 'Ali (1421H), AlFaqih wa al-Mutafaqqih, ed. 'Adil bin Yusuf al-Gharazi, Saudi: Dar Ibn al-Jawzi.

Al-Khatib al-Baghdadi, Abu Bakr Ahmad bin 'Ali bin Thabit (tt.), Al-Kifayah fi 'Ilm al-Riwayah, ed. Abu 'Abdullah al-Suraqi dan Ibrahim Hamdi al-Madani, (Madinah: al-Maktabah al'Ilmiyyah.

Al-Khattabi, Abu Sulayman Hamd bin Muhammad bin Ibrahim (1932), Ma 'alim al-Sunan, Halb: al-Matba'ah al-'Ilmiyyah.

Al-Malyabari, Hamzah 'Abd Allah SWT (2001), al-Muwazanah Bayna al-Mutaqaddimin wa al-Muta'akhkhirin fi Tashih alAhadith wa Ta 'liliha, Beirut: Dar Ibn Hazm.

Al-Nawawi (tt.), Majmu' Sharh al-Muhadhdhab, Kaherah: Dar alFikr.

Al-Nawawi, Abu Zakariyya Yahya bin Sharaf (1985), Al-Taqrib wa al-Taysir li Ma 'rifah Sunan al-Bashir wa al-Nadhir, ed. Muhammad 'Uthman al-Khasyat, (Beirut: Dar al-Kitab al'Arabi. 
Al-Nawawi, Abu Zakariyya Yahya bin Sharaf (2002), Irshad Tullab al-Haqaiq ila Ma'rifah Sunan Khayr al-Khalaiq, ed. Nuruddin 'Itr, Dimashq: Dar al-Yamamah.

Al-Razi, Muhammad bin Abi Bakr (1995), Mukhtar al-Sihah, Beirut: Maktabah Lubnan Nashirun.

Al-Sakhawi, Muhammad bin 'Abd al-Rahman (2003), Fath alMughith bi Sharh Alfiyah al-Hadith, ed. 'Ali Hasan 'Ali, Mesir: Maktabah al-Sunnah.

Al-San'ani, al-Amir Muhammad bin Isma'il (1947), Tawdih alAfkar li Ma'ani Tanqih al-Anzar, ed. Muhammad Mahyuddin 'Abd al-Hamid, Madinah: al-Maktabah alSalafiyyah.

Al-Sarakhsi, Muhammad bin Ahmad (tt.), Usul al-Sarakhsi, Beirut: Dar al-Ma'rifah.

Al-Sha'alan, 'Abdul Rahman bin 'Abdullah (2002), Usul Fiqh alImam Malik - Adillatuh al-Naqliyyah, (Saudi: Jami'ah alImam Muhammad bin Sa'ud al-Islamiyyah.

Al-Sha'rani, 'Abd al-Wahhab bin Ahmad (1900), Kashf alGhummah 'an Jami' al-Ummah, (Mesir: al-Tab'ah alMaymanah.

Al-Shafi'i, Muhammad bin Idris (2005), al-Risalah, ed. Ahmad Muhammad Shakir, Kaherah: Maktabah al-Shuruq alDawliyah.

Al-Shafi'i, Muhammad bin Idris (2011), 'Ikhtilaf al-Hadith' dalam al-Umm, ed. Dr. Rif'at Fawzi 'Abd al-Muttalib, (Beirut: Dar Ibn Hazm, ,

Al-Shatibi, Ibrahim bin Musa bin Muhammad al-Ghirnati (1997), Al-Muwafaqat, ed. Mashhur bin Hasan Ali Salman, Madinah: Dar Ibn 'Affan.

Al-Shawkani, Muhammad bin 'Ali bin Muhammad (1999), Irshad al-Fuhul Ila Tahqiq al-Haq min 'Ilm al-Usul, ed. Ahmad 'Azw 'Inayah, Beirut: Dar al-Kutub al-'Arabi, 1999.

Al-Shirazi; Abu Ishaq Ibrahim bin 'Ali (2014), al-Luma' fi Usul al-Fiqh, Beirut: Dar al-Kutub al-'Ilmiyyah.

Al-Susiwah; 'Abd al-Majid Muhammad Isma'il (1997), Manhaj al-Tawfiq wa al-Tarjih Bayna Mukhtalif al-Hadith wa Atharuhu fi al-Fiqh al-Islami, Beirut: Dar al-Dhakhair. 
Al-Suyuti, Jalal al-Din 'Abd al-Rahman bin Abi Bakr (1979), Tadrib al-Rawi fi Sharh Taqrib al-Nawawi, Beirut: Dar alKutub al-'Ilmiyyah.

Al-Tahawi, Ahmad bin Muhammad al-Azdi (1994), Sharh Maani al-Athar, ed. Muhammad Zuhri al-Najjar dan Muhammad Sayyid Jad al-Haq, Madinah: 'Alam al-Kutub.

Al-Tahawi, Ahmad bin Muhammad al-Azdi (1994), Sharh Mushkil al-Athar, ed. Syu'ayb al-Arnauth, Beirut: Muassasah al-Risalah.

Al-Tibrizi, Abu al-Hasan 'Ali bin Abi Muhammad 'Abdullah (2008), Al-Kafi fi 'Ulum al-Hadith, ed. Abu 'Ubaydah Mashhur bin Hasan Ali Salman, 'Amman: al-Dar alAthariyyah.

Al-Zabidi, Muhammad bin Muhammad bin 'Abdil Razzaq (tt.), Taj al- 'Arus min Jawahir al-Qamus, Beirut: Dar al-Hidayah. Al-Zamakhshari, Mahmud bin 'Umar (tt.), al-Kashshaf 'an Haqaiq al-Tanzil wa 'Uyun al-Aqawil fi Wujuh al-Ta'wil, Beirut: Dar Ihya' al-Turath al-'Arabi.

Faisal Ahmad Shah (2015), Kaedah Tepat Memahami Hadis, Kuala Lumpur: Penerbit Universiti Malaya.

Hakimah Hafizi (2013), Mukhtalif al-Hadith: Mudhazzikah Muqaddimah li Talabah al-Sanah al-Thalithah, Algeria: Jami'ah al-Amir 'Abd al-Qadir li al-'Ulum al-Islamiyyah.

Hasan bin 'Abd al-Hamid bin 'Abd al-Hakim Bukhari (1422H), Manhaj al-Imam al-Tahawi fi Daf' al-Ta'arud Bayn alNusus al-Shar 'iyyah Min Khilal Kitabihi Sharh Mushkil alAthar, tesis sarjana, Jami'ah Umm al-Qura, Mekah.

Ibin Nizam al-Din, 'Abd al-'Ali Muhammad bin Nizam al-Din alSahalawi (2002), Fawatih al-Rahamut bi Sharh Musallam al-Thubut, Beirut: Dar al-Kutub al-'Ilmiyyah.

Ibn 'Abd al-Barr, Abu 'Amru Yusuf bin 'Abdullah (1387H), AlTamhid lima fi al-Muwatta' min al-Ma 'ani wa al-Asanid, ed. Mustafa bin Ahmad al-'Alawi dan Muhammad 'Abd alKabir al-Bakri, Maghribi: Wizarah 'Umum alAwqaf wa alShuun al-Islamiyyah.

Ibn al-Mulaqqin, Abu Hafs 'Umar bin Ahmad (1413H), Al-Muqni ' fi 'Ulum al-Hadith, ed. 'Abdullah bin Yusuf al-Juday', Saudi: Dar Fawwaz. 
Ibn al-Mundhir, Abu Bakr Muhammad bin Ibrahim 1985), AlAwsat fi al-Sunan wa al-Ijma' wa al-Ikhtilaf, ed. Abu Hammad Saghir Ahmad, Riyad: Dar Tayyibah.

Ibn al-Qayyim, Abu 'Abdullah Muhammad bin Abi Bakr alJawziyah (1423H), I'lam al-Muqi 'in 'an Rabb al-'Alamin, ed. Abu 'Ubaydah Mashhur bin Hasan Ali Salman, Saudi: Dar Ibn al-Jawzi.

Ibn Daqiq al-'Id; Muhammad bin 'Ali bin Wahb (2005), Ihkam alAhkam Sharh 'Umdah al-Ahkam, ed. Mustafa Shaykh Mustafa, Beirut: Muassasah al-Risalah.

Ibn Faris, Ahmad bin Faris bin Zakariyya (1979), Mu'jam Maqayis al-Lughah, ed. 'Abd al-Salam Muhammad Harun, Kaherah: Dar al-Fikr.

Ibn Hajar, Ahmad bin 'Ali al-'Asqalani (2012), Nuzhah al-Nazar fi Tawdih Nukhbah al-Fikr fi Mustalah Ahl al-Athar, ed. Nur al-Din 'Itr, Karachi: Maktabah al-Bushra.

Ibn Hazm, Abu Muhammad 'Ali bin Ahmad bin Sa'id bin Hazm (tt.), Al-Ihkam fi Usul al-Ahkam, ed. Ahmad Muhammad Shakir, Beirut: Dar al-Afaq al-Jadidah.

Ibn Jama'ah, Muhammad bin Ibrahim (1404H), Al-Manhal alRawi fi Mukhtasar 'Ulum al-Hadith al-Nabawi, ed. Dr. Mahyuddin 'Abd al-Rahman Ramadan, Dimasyq: Dar alFikr.

Ibn Kathir, Abu al-Fida' Isma'il bin 'Umar (t.t.), Ikhtisar 'Ulum al-Hadith, ed. Ahmad Muhammad Shakir, Beirut: Dar alKutub al-'Ilmiyyah.

Ibn Khuzaymah, Muhammad bin Ishaq al-Naysaburi (1970), Sahih Ibn Khuzaymah, ed. Muhammad Mustafa al-A'zami, Beirut: al-Maktab al-Islami.

Ibn Manzur, Muhammad bin Mukram (1414H), Lisan al-'Arab, Beirut: Dar al-Sadir.

Ibn Salah, Abu 'Amru 'Uthman bin 'Abd al-Rahman alShahrazuri (2010), Muqaddimah Ibn al-Salah, Kaherah: Dar al-Hadith.

Jawwad Muhammad Ahmad Darwish (2001), Manhaj Ibn Hajar fi Mukhtalif al-Hadith min Khilal Kitabihi Fath al-Bari Sharh Sahih al-Bukhari: 'Ard wa Tahlil, tesis sarjana, Ghazzah: alJami'ah al-Islamiyyah. 
Mahmud Sidqi al-Habbash (2001), Al-Muwazanah Bayn Manhajay al-Imamayn al-Shafi i wa Ibn Qutaybah min Khilal Kitabayhima Ikhtilaf al-Hadith wa Ta'wil Mukhtalif al-Hadith, tesis sarjana, al-Jami'ah al-Islamiyyah Ghazzah, Palestin.

Majid bin 'Ali al-Ghamidi (2015), Mukhtalif al-Hadith 'Inda alQadi 'Iyad min Khilal Kitabihi Ikmal al-Mu 'lim: Jam' an wa Dirasah Muqaranah, tesis sarjana, Jami'ah Umm al-Qura, Arab Saudi.

Munirah binti 'Abdullah bin Salih al-'Iskir (1436H), Mukhtalif alHadith Inda al-Qadi Ibn al- 'Arabi fi Kitabihi al-Masalik fi Sharh Muwatta' Malik: Jam 'wa Dirasah, tesis kedoktoran, Jami'ah al-Malik Sa'ud, Sa'udi.

Munirah binti 'Abdullah bin Salih al-'Iskir (1436H), Mukhtalif alHadith Inda al-Qadi Ibn al- 'Arabi fi Kitabihi al-Masalik fi Sharh Muwatta' Malik: Jam 'wa Dirasah, tesis kedoktoran, Jami'ah al-Malik Sa'ud, Sa'udi.

Nafidh Husayn Hammad (2009), Mukhtalif al-Hadith Bayn alFuqaha' wa al-Muhaddithin, Beirut: Dar al-Nawadir.

Nafidh Husayn Hammad (2012), "Manhaj al-Imam al-Shafi'i fi Nasikh al-Hadith wa Mansukhihi", dalam Mu'tamar alImam al-Shafi $i$, ed. Shadi Hamzah Tabazah, Kuliyyah alAdab wa al-'Ulum al-Insaniyyah, Jami'ah al-Aqsa.

Nur al-Din 'Itr (1979), Manhaj al-Naqd 'Inda 'Ulama' al-Hadith, Beirut: Dar al-Fikr.

Salih bin Ahmad bin Hanbal (1999), Masail al-Imam Ahmad bin Hanbal - Riwayat Ibnihi Abi al-Fadl Salih, ed. Tariq bin 'Iwadullah bin Muhammad, Riyad: Dar al-Watan.

Samirah Ibrahim Hamdan Ikhziq (2013), Manhaj al-'Ayni fi Mukhtalif al-Hadith: Dirasah Tatbiqiyyah 'Ala Kitabihi 'Umdah al-Qari Sharh Sahih al-Bukhari, tesis sarjana, alJami'ah al-Islamiyyah Ghazzah, Palestin.

Sharaf al-Qudah (2001), 'Ilm Mukhtalif al-Hadith:Usuluh wa Qawa'iduh, Majallah Dirasah, al-Jami'ah al-Urduniyyah, jilid 28.

Sharaf al-Qudah (2003), Al-Minhaj al-Hadith fi 'Ulum al-Hadith, Jordan: al-Akadimiyyun li al-Nashr wa al-Tawzi'. 
Syabbir bin Ahmad al-'Uthmani (2016), Mabadi' 'Ilm al-Hadith wa Usuluh, ed. 'Abd al-Fattah Abu Ghuddah, Kaherah, Dar al-Salam.

The University of Jordan, Dr. Sharaf al-Qudah, dicapai 10 Ogos 2020, http://eacademic.ju.edu.jo/S.AlQudah/Pages/AboutMe.aspx.

Usamah bin 'Abd Allah Khayyat (2001), Mukhatalif al-Hadith Bayn al-Muhaddithin wa al-Usuliyyin al-Fuqaha', Beirut: Dar Ibn Hazm.

Wahbah al-Zuhayli (2009), Usul al-Figh al-Islami, Dimashq: Dar al-Fikr.

'Abd al-Rahīm bin al-Ḥusayn al-'Irāqī, Al-Taqyìd wa al-Iḍāh Sharh Muqaddimah Ibn al-Salāh, ed. 'Abd al-Raḥman Muhammad 'Uthmān. Madinah: al-Maktabah al-Salāfiyyah, 1969.

'Abdullah Murtaji, 'Abd Allāh Mușțafā Sa'īd. "Manhaj al-Imām al-Bukhārī fì Mukhtalif al-Ḥadīth fī Șạ̣ịhihi wa alMuwāzanah Baynahu wa Bayna Manhaj al-Imām alTirmidhī fì Mukhtalif al-Hadìth fì Jami'ihi”. Tesis kedoktoran, Jāmi'ah al-Qur'ān al-Karīm wa al-'Ulūm li alIslāmiyyah, Sudan, 2000.

'Itr, Nūr al-Dīn. Manhaj al-Naqd 'Inda 'Ulamā' al-Hadìth. Beirut: Dār al-Fikr, 1979.

"Dr. Sharaf al-Qudah", laman sesawang The University of Jordan, dicapai 10 Ogos 2020, http://eacademic.ju.edu.jo/S.AlQudah/Pages/AboutMe.aspx.

Abādī, Muḥammad Abū al-Layth al-Khayr. 'Ulūm al-Hadìth Așiluhā wa Mu'asiruhā. Selangor: Darul Syakir, 2011.

Ahmad Darwish, Jawwad Muḥammad. "Manhaj Ibn Hajar fì Mukhtalif al-Hadīth min Khilal Kitābihi Fatḥ al-Bārī Sharḥ Șahịh al-Bukhārī: ‘Ard wa Taḥlīl’. Disertasi, al-Jāmi'ah alIslamiyyah, Gaza, 2001.

Aḥmad, Abū Hafs 'Umar bin. Al-Mughnī' fì 'Ulūm al-Hadìth, ed. 'Abd Allāh bin Yūsuf al-Juday'. Arab Saudi: Dār Fawwaz, 1992.

Al-'Irāqī, 'Abd al-Rahīm bin Husayn. Sharh al-Tabshīrah wa alTadhkirah, ed. Māhir Yasīn al-Fahl dan 'Abd al-Lațîf alHamim. Beirut: Dār al-Kutub al-'Ilmiyyah, 2002. 
Al-'Iskir, Munīrah bint 'Abd Allāh bin Șāliḥ. "Mukhtalif al-Hadīth Inda al-Qādī Ibn al-'Arābī fì Kitābihi al-Masālik fī Sharḥ Muwaț̣ā' Mālik: Jam‘ wa Dirāsah”. Tesis kedoktoran, Jāmi'ah al-Mālik Sa'ūd, Arab Saudi, 2015.

Al-'Uthmānī, Shabbir bin Aḥmad. Mabādi' 'Ilm al-Hadīth wa Ușūluh, ed. 'Abd al-Faț̣āḥ Abū Ghuḍāh. Kaherah: Dār alSalam, 2016.

Al-Baghdādī, Abū Bakr Aḥmad bin 'Alī bin Thābit al-Khāṭib. AlKifāyah fì 'Ilm al-Riwāyah, ed. Abū 'Abd Allāh al-Suraqi dan Ibrāhīm Hamdi al-Madānī. Madinah: al-Maktabah al'Ilmiyyah, t.t.

Al-Bayhāqī, Abū Bakr Aḥmad ibn Husayn Ibn 'Alī. Al-Khilāfiyyāt Bayna al-Imāmayn al-Shāfi '⿳亠 wa Abū Hanīfah wa Ashāabih, ed. Mashhūr bin Hasan 'Alī Salmān. Riyadh: Dār al-Sami'i, 1994.

Al-Daghistani, Murtaḍā 'Alī bin Muḥammad. Al-Madkhal ilā Ușūl al-Imām al-Shāfi ‘̀ min Khilal Tuhfah al-Muhtāj bi Sharh alManhaj. Damsyik: al-Mashrīq li al-Kitāb, 2008.

Al-Dusārī, Sa'd Fajhan. Qawā'id Raf' al-Ikhtilāf fì al-Hadìth alNabāwī. Beirut: Muassasah al-Risālah, 2011.

Al-Fayrūz Abādī, Muḥammad bin Ya'qūb. Al-Qāmūs al-Muhịt, ed. Muhammad Na'ìm al-'Arqasusi. Beirut: Muassasah alRisālah, 2005.

Al-Fayyūmī, Aḥmad bin Muḥammad bin 'Alī. Al-Miṣbāh alMunīr fì Gharīb al-Sharh al-Kabìr li al-Rafi 'i. Beirut: alMaktabah al-'Ilmiyyah, t.t.

Al-Ghāmid̄̄, Mājid bin "Alī. "Mukhtalif al-Ḥadīth "Inda al-Qāộ̄ 'Iyāḍ min Khilal Kitābihi "Ikmal al-Mu'lim": Jam'an wa Dirāsah Muqāranah". Disertasi, Jāmi'ah Umm al-Qurā, Arab Saudi, 2015.

Al-Ghirnatī, Ibrāhīm bin Mūsā bin Muḥammad. Al-Muwāfaqāt, ed. Mashhur bin Hasan 'Alī Salmān. Madinah: Dār Ibn 'Affān, 1997.

Al-Ḥabbash Mạ̣mūd Șidqī. "Al-Muwāzanah Bayna Manhajay alImāmayn al-Shāfi'‘ wa Ibn Qutaybah min Khilal Kitābayhima Ikhtilāf al-Hadìth wa Ta'wīl Mukhtalif alḤadīth”. Disertasi, al-Jāmi'ah al-Islāmiyyah Ghazzah, Palestin, 2001. 
Al-Ḥākim, Abū 'Abd Allāh Muḥammad bin 'Abd Allāh. Ma 'rifah 'Ulūm al-Hadīth. Beirut: Dār al-Kutub al-'Ilmiyyah, 1977.

Al-Hammādī, 'Abd Allāh bin Jābir. Mukhtalif al-Hadīth 'Inda alImām Ibn 'Abd al-Barr: 'Ard wa Dirāsah. Riyadh: Dār Kunūz Ishbiliya, 2012.

Al-Hāzimī Abū Bakr Muhammad bin Mūsā bin 'Uthmān. AlI'tibar fì al-Nāsikh wa al-Mansūkh min al-Athār,. Hyderabad: Dai'rah al-Ma'ārif al-'Uthmāniyyah, 1938.

Al-Jurjān̄̄, 'Al̄̄ bin Muḥammad bin 'Alī al-Zayn al-Sharīf. Kitāb al-Ta'rīfāt. Beirut: Dār al-Kutub al-'Ilmiyyah, 1983.

Al-Kattān̄̄, Muhammad bin Ja'far. Al-Risālah al-Mustatrifah li Bayān Mashhur Kutub al-Sunnah al-Mușannafah. Cet. 4, Beirut: Dār al-Bashā'ir al-Islāmiyyah, 1986.

Al-Khaț̣ābī, Abū Sulaymān Hamd bin Muḥammad bin Ibrāhīm. Ma 'álim al-Sunan. Halab: al-Mațba'ah al-'Ilmiyyah, 1932.

Al-Laknāwī, Muḥammad 'Abd al-Hayy. Al-Ajwibah al-Faḍ̄lah li al-As'ilah al-'Ashrah al-Kamilah, ed. 'Abd al-Fattạh Abū Ghuḍāh. Beirut: Maktab al-Matbū'at al-Islāmiyyah, 1984.

Al-Malyabārī, Hamzah 'Abd Allāh. Al-Muwāzanah Bayna alMutaqaddimīn wa al-Muta'akhkhirīn fì Taṣhīh al-Ahāoìth wa Ta 'liliha. Beirut: Dār Ibn Hazm, 2001.

Al-Nawāwī Abū Zakariyyā Yaḥyā bin Sharaf. Irshād Tullab alHaqā'iq ilā Ma'rifah Sunan Khayr al-Khalā'iq, ed. Nuruddin 'Itr. Damsyik: Dār al-Yamamah, 2002.

Al-Nawāwī, Abū Zakariyyā Yaḥya bin Sharaf. Al-Taqrīb wa alTaysir li Ma'rifah Sunan al-Bashir wa al-Nadir, ed. Muhammad 'Uthmān al-Khasyat. Beirut: Dār al-Kitab al'Arabī, 1985.

Al-Nawāwī, Abū Zakariyyā Yahyyā ibn Sharaf. Al-Minhaj Sharh Șahịh Muslim bin al-Hajjāj. Beirut: Dār Ihyā' al-Turath al'Arabi, 1932.

Al-Nawāwī, Abū Zakariyyā Yahyā ibn Sharaf. Majmū' Sharh alMuhadhdhab. Kaherah: Dār al-Fikr, t.t.

Al-Quḍāh, Sharaf. "IIlm Mukhtalif al-Hadītḥ: Ușūluh wa Qawā'iduh", Majallāh Dirāsah al-Jāmi'ah al-Urduniyyah, jilid 28 (2001), 17.

Al-Quḍāh, Sharaf. Al-Minhaj al-Hadīth fì 'Ulūm al-Hadìth. Jordan: al-Akadimiyyūn li al-Nashr wa al-Tawzī', 2003. 
Al-Rāzī, Muḥammad bin Ab̄̄ Bakr. Mukhtār al-Ṣiḥaḥ. Beirut: Maktabah Lubnān Nashirun, 1995.

Al-Sahalāwī, 'Abd al-'Al̄̄ Muhammad bin Niẓām al-Dīn. Fawātih al-Rahamut bi Sharh Musallam al-Thubut. Beirut: Dār al-Kutub al-'Ilmiyyah, 2002.

Al-Sakhāwī, Muḥammad bin 'Abd al-Raḥman. Fath al-Mughìth bi Sharh Alfiyah al-Hadīth, ed. 'Alī Hasan 'Alī. Mesir: Maktabah al-Sunnah, 2003.

Al-Ṣan‘ān̄i, Muhammad bin Ismā‘̄il. Tawdīh al-Afkār li Ma 'ānī Tanqih al-Anzar, ed. Muhammad Mahyy al-Dīn 'Abd alḤāmid. Madinah: al-Maktabah al-Salāfiyyah, 1947.

Al-Sarakhsī, Muḥammad bin Aḥmad. Ușūl al-Sarakhsī. Beirut: Dār al-Ma'rifah, t.t.

Al-Sha'alan, 'Abd al-Raḥman bin 'Abd Allāh. Ușūl Fiqh al-Imām Mālik - Adillatuh al-Naqliyyah. Arab Saudi: Jāmi'ah alImām Muhammad bin Sa'ūd al-Islāmiyyah, 2002.

Al-Sha'rānī, 'Abd al-Wahhāb bin Aḥmad. Kashf al-Ghummah 'an Jami' al-Ummah. Mesir: al-Țab'ah al-Maymanah, 1900.

Al-Shāfi'ī, Muhammad ibn Idrīs. "Ikhtilāf al-Hadīth" dalam alUmm, ed. Rif'āt Fawz̄i 'Abd al-Muțālib. Beirut: Dār Ibn Hazm, 2011.

Al-Shāfi'‘̄, Muhammad ibn Idrīs. Al-Risālah, ed. Aḥmad Muhammad Shākir. Kaherah: Maktabah al-Shurūq alDawliyyah, 2005.

Al-Shātịī, Ibrāhim bin Mūsā bin Muhammad al-Ghirnatī. AlMuwāfaqāt, ed. Mashhūr bin Hasan 'Alī Salmān. Madinah: Dār Ibn 'Affān, 1997.

Al-Shirāzī, Abū Isḥāq Ibrāhīm bin 'Alī. Al-Lumā' fì Ușūl al-Fiqh. Beirut: Dār al-Kutub al-'Ilmiyyah, 2014.

Al-Susiwah, 'Abd al-Mājid Muhammad Ismā'īl. Manhaj alTawfì wa al-Tarjīh Bayna Mukhtalif al-Hadìth wa Athāruhu fì al-Fiqh al-Islāmī. Beirut: Dār al-Dhakha'ir, 1997.

Al-Suyūṭ̄i, Jalāl al-Dīn 'Abd al-Raḥman bin Abī Bakr. Al-Itqān fì 'Ulūm al-Qur'ān, ed. Muḥammad Abū al-Faḍl Ibrāhīm. Kaherah: al-Hay'ah al-Mișriyyah al-'Āmmah, 1974.

Al-Suyūṭ̣̂, Jalāl al-Dīn 'Abd al-Raḥman bin Abī Bakr. Tadrīb alRāwì fì Shah Taqrīb al-Nawāwī. Beirut: Dār al-Kutub al'Ilmiyyah, 1979. 
Al-Ṭahāwī, Abū Ja'far Aḥmad al-Ṭaḥāwī Sharh Ma'ānī al-Athār ed. Muḥammad Zuhrī al-Najjār dan Muḥammad Sayyīd Jād al-Haq. Madinah: 'Alam al-Kutub, 1994.

Al-Ṭaḥāwī, Aḥmad bin Muhammad al-Azdī. Sharh Mushkil alAthār, ed. Syu'ayb al-Arnauth. Beirut: Muassasah alRisālah, 1994.

Al-Tibrizīe Abū al-Hasan 'Alī bin Abī Muhammad 'Abd Allāh. AlKäfì fì 'Ulūm al-Hadìth, ed. Abū 'Ubaydah Mashhūr bin Hasan 'Alī Salmān. Amman: al-Dār al-Athāriyyah, 2008.

Al-Zābid̄̄, Muḥammad bin Muḥammad bin 'Abd al-Razzāq. Tāj al- 'Arūs min Jawāhir al-Qāmūs. Beirut: Dār al-Hidāyah, t.t.

Al-Zuhaylī, Wahbah. Ușūl al-Fiqh al-Islāmī. Damsyik: Dār alFikr, 2009.

Bukhārī, Hasan bin 'Abd al-Ḥāmid bin 'Abd al-Ḥākim. "Manhaj al-Imām al-Ṭahāwī fĩ Daf' al-Ta'arruḍ Bayna al-Nușūṣ alShar 'iyyah min Khilal Kitābihi Sharḥ Mushkil al-Athār". Disertasi, Jāmi‘ah Umm al-Qura, Mekah, 2001.

Faisal Ahmad Shah. Kaedah Tepat Memahami Hadis. Kuala Lumpur: Penerbit Universiti Malaya, 2015.

Hāfizī, Hākimah. Mukhtalif al-Hadìth: Mudhazzikah Muqaddimah li Talabah al-Sanah al-Thālithah. Algeria: Jāmi'ah al-Amir 'Abd al-Qādir li al-'Ulūm al-Islāmiyyah, 2013.

Hāj, Abū 'Abd Allāh Shams al-Dīn Muḥammad bin Muḥammad Amīr. Al-Taqrīr wa al-Tahbir. Beirut: Dār al-Kutub al'Ilmiyyah, 1983.

Hammad, Nafidh. "Manhaj al-Imām al-Shāfi'î fì Nāsikh al-Hadīth wa Mansūkhihi”, dalam Mu'tamar al-Imām al-Shāfi'‘', ed. Shādī Hamzah Tabazah. Kuliyyah al-Ādāb wa al-'Ulūm alInsāniyyah, Jāmi'ah al-Aqsa, 2012.

Hammad, Nafidh. Mukhtalif al-Hadìth Bayn al-Fuqahā' wa alMuhaddithīn. Beirut: Dār al-Nawādir, 2009.

Hanbal, Șāliḥ bin Aḥmad bin. Masā'il al-Imām Ahmad bin Hanbal

- Riwayat Ibnihi Abī al-Fạ̣l Șāliḥ, ed. TTarīq bin 'Iwad Allāh bin Muḥammad. Riyadh: Dār al-Wațan, 1999.

Ibn 'Abd al-Barr, Abū 'Amrū Yūsuf bin 'Abd Allāh. Al-Tamhīd limā fi al-Muwattā' min al-Ma'ān̄̄ wa al-Asānid, ed. Muștafa bin Aḥmad al-"Alawī dan Muḥammad 'Abd alKabīr al-Bakrī. Maghribi: Wizārah 'Umūm al-Awqāf wa alShu'un al-Islāmiyyah, 1966. 
Ibn al-Mundhīr, Abū Bakr Muḥammad bin Ibrāhīm. Al-Awsaṭ fì al-Sunan wa al-Ijmā' wa al-Ikhtilāf, ed. Abū Ḥammād Saghīr Aḥmad. Riyadh: Dār Ṭayyibah, 1985.

Ibn al-Qayyīm, Muḥammad bin Abī Bakr al-Jawziyah. I'lam alMuqi 'in 'an Rabb al-'Alamīn, ed. Abū 'Ubaydah Mashhūr bin Hasan 'Alī Salmān. Arab Saudi: Dār Ibn al-Jawzī, 2002.

Ibn Fāris, Aḥmad bin Fāris bin Zakariyyā. Mu'jam Maqāyis al-

Lughah, ed. 'Abd al-Salam Muhammad Hārun. Kaherah: Dār al-Fikr, 1979.

Ibn Hajar al-'Asqalānī, Aḥmad bin 'Alī. Nuzhah al-Nazar fì Tawdih Nukhbah al-Fikr fì Muștalah Ahl al-Athār, ed. Nūr al-Dīn 'Itr. Karachi: Maktabah al-Bushrā, 2012.

Ibn Ḥazm, Abū Muḥammad 'Alī bin Aḥmad bin Sa'id. Al-Iḥkām fì Ușūl al-Aḥkām, ed. Aḥmad Muḥammad Shākir. Beirut: Dār al-Āfāq al-Jadīdah, t.t.

Ibn Jama'ah, Muhammad bin Ibrāhīm. Al-Manhal al-Rāwī fì Mukhtașar 'Ulūm al-Hadìth al-Nabāwī, ed. Mahy al-Dīn 'Abd al-Raḥman Ramāḍān. Damsyik: Dār al-Fikr, 1983.

Ibn Kathīr, Ismā'īl bin 'Umar. Ikhtișār 'Ulūm al-Hadìth, ed. Ahmad Muhammad Shākir. Beirut: Dār al-Kutub al'Ilmiyyah, t.t.

Ibn Khuzaymah, Muḥammad bin Isḥāq al-Naysabūrī. Șahīh Ibn Khuzaymah, ed. Muhammad Muștafā al-A 'zamī. Beirut: alMaktab al-Islāmī, 1970.

Ibn Manzūrr, Muhammad bin Mukarram. Lisān al-'Arab. Beirut: Dār al-Șādir, 1993.

Ibn Șalah, Abū 'Amrū 'Uthmān bin 'Abd al-Raḥman alShahrazūrī. Muqaddimah Ibn al-Șalah. Kaherah: Dār alHadīth, 2010.

Ikhziq, Samīrah Ibrāhīm Ḥamdan. "Manhaj al-'Aynī fī Mukhtalif al-Ḥadīth: Dirāsah Taṭbiqiyyah 'alā Kitābihi 'Umdah al-Qārī Sharḥ Șaḥị̣ al-Bukhārī”. Disertasi, al-Jāmi'ah al-Islāmiyyah Gaza, Palestin, 2013.

Khayyāt, Usāmah bin 'Abd Allāh. Mukhatalif al-Hadìth Bayna alMuhaddīthīn wa al-Ușūliyyìn al-Fuqahā'. Beirut: Dār Ibn Hazm, 2001.

Rushu, Al-Hādī. Mukhtalif al-Hadīth wa Juhud al-Muhaddīthīn fìh: Dirāsah Naqdiyyah. Beirut: Dār Ibn Hazm, 2009. 
Wahab, Muhammad bin 'Alī bin. Ihkām al-Ahkam Sharh 'Umdah al-Aḥkām, ed. Muștafā Shaykh Muștafā. Beirut: Muassasah al-Risālah, 2005.

Zaydan, 'Abd al-Karīm. Al-Wajīz fì Sharh al-Qawā'id alFiqhiyyah. Beirut: Muassasah al-Risālah Nashirun, 2014.

Zaydān, 'Abd al-Karīm. Al-Wājīz fì Ușūl al-Fiqh. Beirut: Muassasah al-Risālah Nashirun, 2013. 